\title{
A systematic review of proteomic biomarkers in oral squamous cell cancer
}

\author{
Jyotsnaa Pillai ${ }^{1}$, Tanvi Chincholkar ${ }^{1}$, Ruhi Dixit ${ }^{2}$ and Manoj Pandey ${ }^{2^{*}}$ (D)
}

\begin{abstract}
Background: Head and neck squamous cell cancer (HNSCC) is the most common cancer associated with chewing tobacco, in the world. As this is divided in to sites and subsites, it does not make it to top 10 cancers. The most common subsite is the oral cancer. At the time of diagnosis, more than $50 \%$ of patients with oral squamous cell cancers (OSCC) had advanced disease, indicating the lack of availability of early detection and risk assessment biomarkers. The new protein biomarker development and discovery will aid in early diagnosis and treatment which lead to targeted treatment and ultimately a good prognosis.

Methods: This systematic review was performed as per PRISMA guidelines. All relevant studies assessing characteristics of oral cancer and proteomics were considered for analysis. Only human studies published in English were included, and abstracts, incomplete articles, and cell line or animal studies were excluded.

Results: A total of 308 articles were found, of which 112 were found to be relevant after exclusion. The present review focuses on techniques of cancer proteomics and discovery of biomarkers using these techniques. The signature of protein expression may be used to predict drug response and clinical course of disease and could be used to individualize therapy with such knowledge.

Conclusions: Prospective use of these markers in the clinical setting will enable early detection, prediction of response to treatment, improvement in treatment selection, and early detection of tumor recurrence for disease monitoring. However, most of these markers for OSCC are yet to be validated.
\end{abstract}

Keywords: Head and neck cancer, Proteomics, Biomarkers, Oral cancer

\section{Background}

Oral squamous cell cancer (OSCC) is the most common malignant neoplasm arising in the mucosa of oral cavity and includes subsites like the buccal mucosa, alveolus (upper and lower) tongue, palate, and lip [1]. Head and neck cancer accounts for more than 550,000 cases worldwide annually [2]. Oral cancers are more common in the Indian subcontinent, while cancer of the laryngopharynx is more common in other populations [3]. Overall, $57.5 \%$ of global oral cancers occur in Asia especially in India. It

*Correspondence: manojpandey@wjso.com; manojpandey66@gmail.com 2 Department of Surgical Oncology, Institute of Medical Sciences, Banaras Hindu University, Varanasi 221 005, India

Full list of author information is available at the end of the article is $30 \%$ of all cancers in India, of which 60 to $80 \%$ of the patients present with advanced diseases as compared to $40 \%$ in developed countries, this also suggests lack of awareness and need for markers of early identification [4].

Almost all of these malignancies are squamous cell carcinomas (SSCs) which historically in the developed world was associated mostly with alcohol and tobacco consumption and the combination of the two, producing a synergistic increase in the risk. However, over the past 20 years, investigators have found a growing proportion of HNSCC patients with human papillomavirus (HPV) positive tumors that develop in younger people and those having a lower or no intake of tobacco and alcohol, the association in oropharynx is higher than oral cavity [5]. original author(s) and the source, provide a link to the Creative Commons licence, and indicate if changes were made. The images or other third party material in this article are included in the article's Creative Commons licence, unless indicated otherwise in a credit line to the material. If material is not included in the article's Creative Commons licence and your intended use is not permitted by statutory regulation or exceeds the permitted use, you will need to obtain permission directly from the copyright holder. To view a copy of this licence, visit http://creativecommons.org/licenses/by/4.0/. The Creative Commons Public Domain Dedication waiver (http://creativeco mmons.org/publicdomain/zero/1.0/) applies to the data made available in this article, unless otherwise stated in a credit line to the data. 
Improvement in understanding the steps leading to carcinogenesis will enable the identification and prediction of malignant progression at an earlier stage of OSCC. Cancer signifies deviation from normal signaling network toward a dysregulated cellular proliferation. Proteins with linkages to various pathways when altered the functional state may shift the equilibrium of the signaling network to enhance the survival of the affected cells or reduce its apoptosis [6]. Searching for such proteins is the main purpose of cancer proteomics. Proteins being the common molecule that participate in the cellular function are often affected by disease, response to treatment, and being disease free. Development of novel protein biomarkers of OSCC in the light of proteomics can help in early cancer diagnosis, treatment, and prognosis.

\section{Material and methods}

This systematic review was performed as per PRISMA guidelines. A bibliographic search was performed for studies published till August 2021, using PubMed, Cochrane database, Google scholar, the National Library of Medicine, SpringerLink, and Science Open. The keywords used were "proteomic biomarkers," AND "head and neck cancer," AND "oral cancer." The detailed search strategy for PubMed is detailed in Additional file 1. All relevant studies assessing proteomic characteristics of oral cancer and precancers were considered for analysis. Abstracts, incomplete articles, and non-comparative studies and article in language other than English were excluded. We performed a restriction of articles including only studies in humans; studies on cell line and animals were excluded.

The review also discusses proteomics-based techniques that are used in the identification of proteins that are altered in the disease process or in response to treatment or disease stage and course, and such information could be used to individualize therapy. Research findings in the review are highlights from articles focusing on proteomic approaches toward diagnosis and detection of oral cancer; identification of biomarkers through proteolytic analysis carried out using mass spectrometry, 2D electrophoresis, and other proteomic techniques.

\section{Results}

The search revealed 304 articles in English of these this systematic review includes a total of 112 articles (Fig. 1). The review articles were excluded, the two meta-analyses published on the subject has been discussed. These articles were categorized under subsections enumerated below followed by a list of all protein biomarkers identified and brief description of their importance.

\section{Biomarker discovery-a proteomic approach}

A biomarker is "a measurable indicator of a specific biological state relevant to the risk of contraction, presence or the stage of disease." Biomarkers can be clinically used to screen, diagnose, and monitor the activity of disease and to assess therapeutic response [7]. "An ideal biomarker should be sensitive, specific, cost-effective, and robust against situational variability and should have added value beyond that of current standards [8]."

Biomarkers can be carbohydrates, DNA, mRNAs, proteins, or small molecules like metabolites and other cellular molecules [9]. Predictive biomarkers lead to detection of abnormalities that causes the development of OSCC [10], while prognostic biomarkers help in predicting the response to therapy and prognosis of patient. Nucleic acid-based microsatellite analysis and tumor-specific aberrant promoter methylation have been used as markers to detect tumor-specific alterations in body fluid and somatic cells of patients with OSCC $[11,12]$, while this article focuses on protein biomarkers.

Genome sequencing has produced a wealth of information during the last two decades. Following this step was taken to look at proteins, which are the biomolecules translated from genes and govern overall cellular processes. It is proposed that the genes exert their actions through proteins to cause diseases including malignancies. Mechanisms like alternative splicing and post-translational modifications of proteins (e.g., phosphorylation, glycosylation, acetylation, and proteolytic cleavage) contribute to the human proteome that comprises more than half a million proteins $[13,14]$ in comparison with about 22,000 protein-coding genes [15]. Proteins are important cellular molecules that participate in the cellular process and even control synthesis of DNA and its transcription, proteomic techniques can provide greater insight into cellular physiology and molecular biology. Biomarkers are of extreme importance and can be utilized either alone or in combination with other biomarkers. The available tools are able to identify the quality, quantity, and structural modification beside sub cellular localization [16]. However, most of these require validation.

These protein biomarkers can be secreted by tumors and hence could be differentially expressed compared to normal tissue. The fresh tissue is generally required to study the translation while paraffin-embedded tissue can be used for cellular localization and study of expression. Apart from serum, these proteins can be estimated in other body fluids like urine, saliva, sputum, etc.; however, their quantity may vary according to their secretion by the tumor.

Before being analyzed by mass spectrometry (MS), the sample undergoes preliminary separation, enrichment or fractionation of their proteins. The techniques 


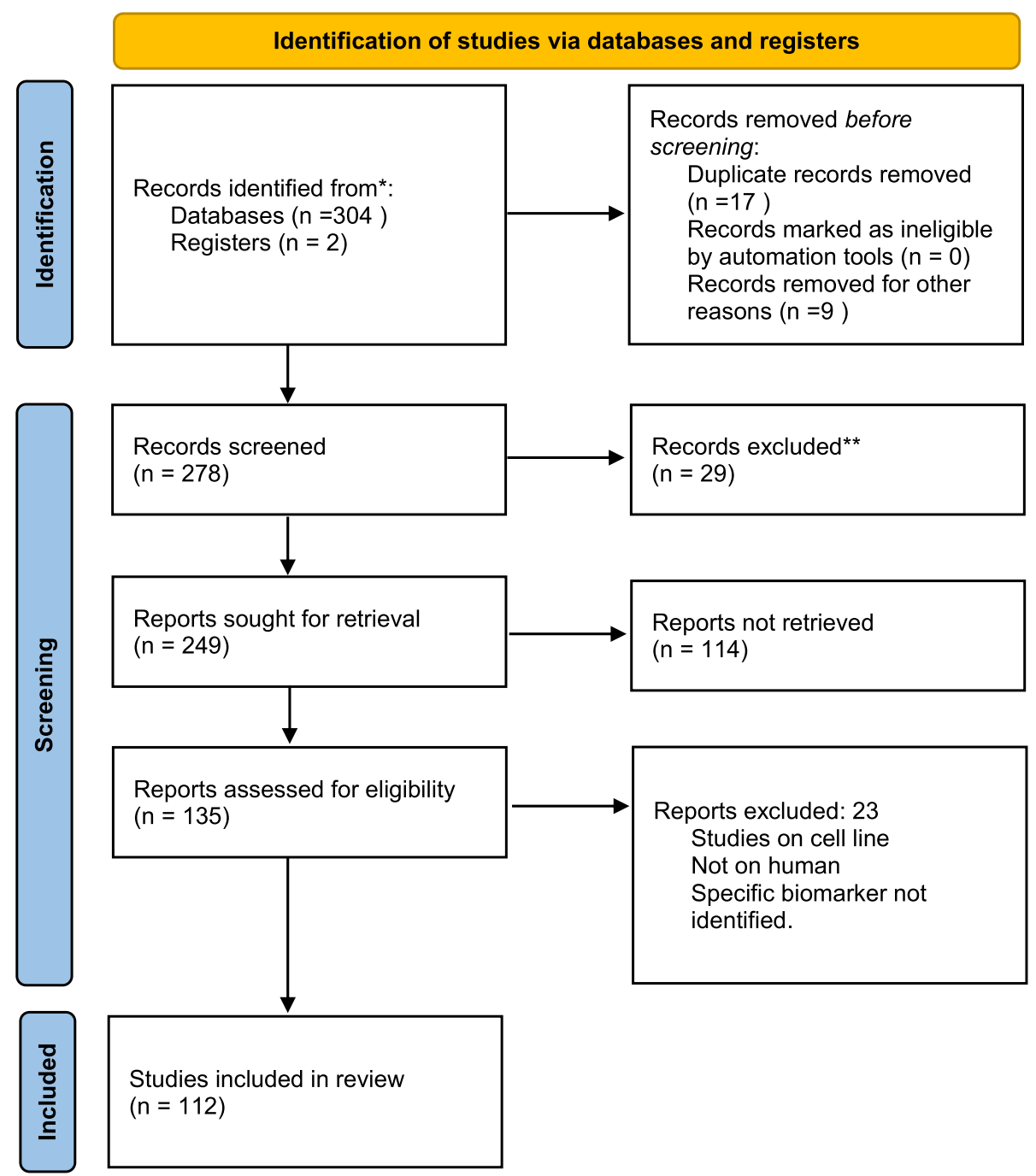

Fig. 1 PRISMA flowchart of studies included in the systematic review

of the enrichments include one-directional polyacrylamide gel electrophoresis (1D-PAGE), two-dimensional polyacrylamide gel electrophoresis (2D-PAGE) among others [17].

Liquid chromatography, coupled to tandem MS (LCMS/MS) is used to identify and quantify proteins from human tissues. This is based on interactions between protein, peptide, and column. First, the separation is done by liquid chromatography before identification by mass spectrometry (MS).

A mass spectrometer (MS) has mainly three components: an ionization source, a mass analyzer, and an ion detector $[18,19]$. The most common ion sources used are electrospray ionization (ESI) and matrix-assisted laser desorption/ionization (MALDI). These sources produce ion from the sample which are then analyzed on mass spectrophotometer. The main ion analyzers used in proteomics are quadrupole $(\mathrm{Q})$, time of flight (TOF), ion traps, and Fourier transform ion cyclotron (FT-ICR). The cellular localization and quantification are usually done by immunohistochemistry and ELISA; these are also used for validation of protein biomarkers.

\section{OSCC biomarkers}

As there is considerable variation in protein expression, there is a variety of potential biomarkers of OSCC. These can be broadly classified in to (i) tissue-based biomarkers, (ii) secretomes (plasma, saliva, blood, or other secretions), and (iii) autoantibodies. 


\section{Potential biomarkers}

Tissue-based biomarkers in head and neck cancer (Table 1)

Majority of selected biomarkers investigated are tissuebased biomarkers by using different approaches and are summarized in Table 1 . The approaches employed include LC-MS, RPLC-MS, SELDI-TOF MS, 2D DGE, iTRAQ, and 2DLC. Further, the results verified by using IHC, PCR, and western blot techniques as described above.

\section{Serum/plasma biomarkers/saliva/secretome (Table 2)}

Majority of selected serum/plasma-based biomarkers by using different approaches are summarized in Table 2. Only a few important ones are discussed.

Epidermal growth factor receptor (EGFR) EGFR is an important member of the family of the membrane-bound tyrosine kinase receptors activated in tumor cells of epithelial origin. This receptor regulates cellular growth, proliferation, apoptosis, differentiation, migration, and secretion of certain proteins [94]. High EGFR expression has been observed in OSCC suggesting that an uncontrolled growth may be mediated by abnormal EGFR expression [82, 124].

Vitamin D-binding protein Vitamin D-binding protein is a secreted transport protein which transports the vitamin D sterols in serum and prevents polymerization of actin. The level of vitamin D-binding protein level was significantly low in OSCC plasma. Plasma fibrinogen is a blood coagulation regulator associated with angiogenic and metastatic prediction in numerous tumors [50]. Vitamin D-binding protein has been used as a biomarker for breast cancer, thyroid cancer, and lung cancer [83]. In oral cancer, it has not been found to be increased in human plasma; however, higher concentrations are observed in mouse plasma [83]. Tung et al. (2013) [82] found vitamin D-binding protein to be reduced in OSCC plasma; these results suggested differential regulation in different species.

Fibrinogen (alpha/beta/gamma chain) Plasma fibrinogen is commonly estimated for blood coagulation and is reported as angiogenic and a metastatic predictor in many tumors [50,84]. The high expression level of serum fibrinogen has been found to be observed in OSCC patients [50]. Fibrinogen beta chain is a blood-borne glycoprotein, functions in inflammatory responses. It has shown elevated expression in OSCC samples [50]. Fibrinogen gamma chain is a gamma component of fibrinogen and has a major function in homeostasis. It can be considered tumor marker, as the protein shows significantly higher expression in OSCC samples compared to the healthy ones [50].

Carcinoembryonic antigen (CEA) CEA is a glycoprotein produced by the cells of gastrointestinal tract during embryonic development and is involved in cell adhesion. The salivary and serum levels of CEA were found to be increased in malignant tumors than in healthy tissues [97]. It has been reported previously that the content of saliva CEA was significantly higher in oral-maxillofacial cancer patients and benign tumor than in normal persons $(P<0.01)$ [97]. Thus, saliva CEA is of guiding significance to a certain extent for identification of malignant and benign tumor, assisting clinical diagnosis and prognosis monitoring of treatment efficacy for cancer [97].

\section{Autoantibodies (Table 3)}

Majority of selected biomarkers investigated autoantibodies-based biomarkers by using different approaches are summarized in Table 3. Few important ones are discussed herein.

P53 autoantibody p53 antibodies are found in serum and saliva of patients showing overexpression of p53 in their tumor tissues. This is an easy process as these can be detected from saliva [125].

Hsp 70 autoantibody HSPs are frequently overexpressed in tumor cells. Autoantibodies directed against HSP70 can discriminate the risk condition between healthy and tumor cells. Its level increases from healthy controls to SCC, suggesting that autoantibodies might be used as both early marker and screening risk marker for SCC [126].

\section{Discussion}

Development of OSCC is a multistep process. Field cancerization is one of the hallmark of oral cancer, wherein the whole of the mucosa of the oral cavity and upper aerodigestive tract undergo molecular changes and is susceptible to develop cancer. Change in the protein expression profile can be a manifestation of the field cancerization and hence its identification is an important biomarker to predict risk of development of cancer, second primary or recurrence of OSCC.

Tobacco and alcohol consumption are the major independent risk factors for development of HNSCC that also show synergy when combined [128]. Oral cancer development risk is 3 to 9 times greater in those who smoke and drink than in those who consume neither of the two $[6,128]$. The upper aerodigestive tract is first to make 


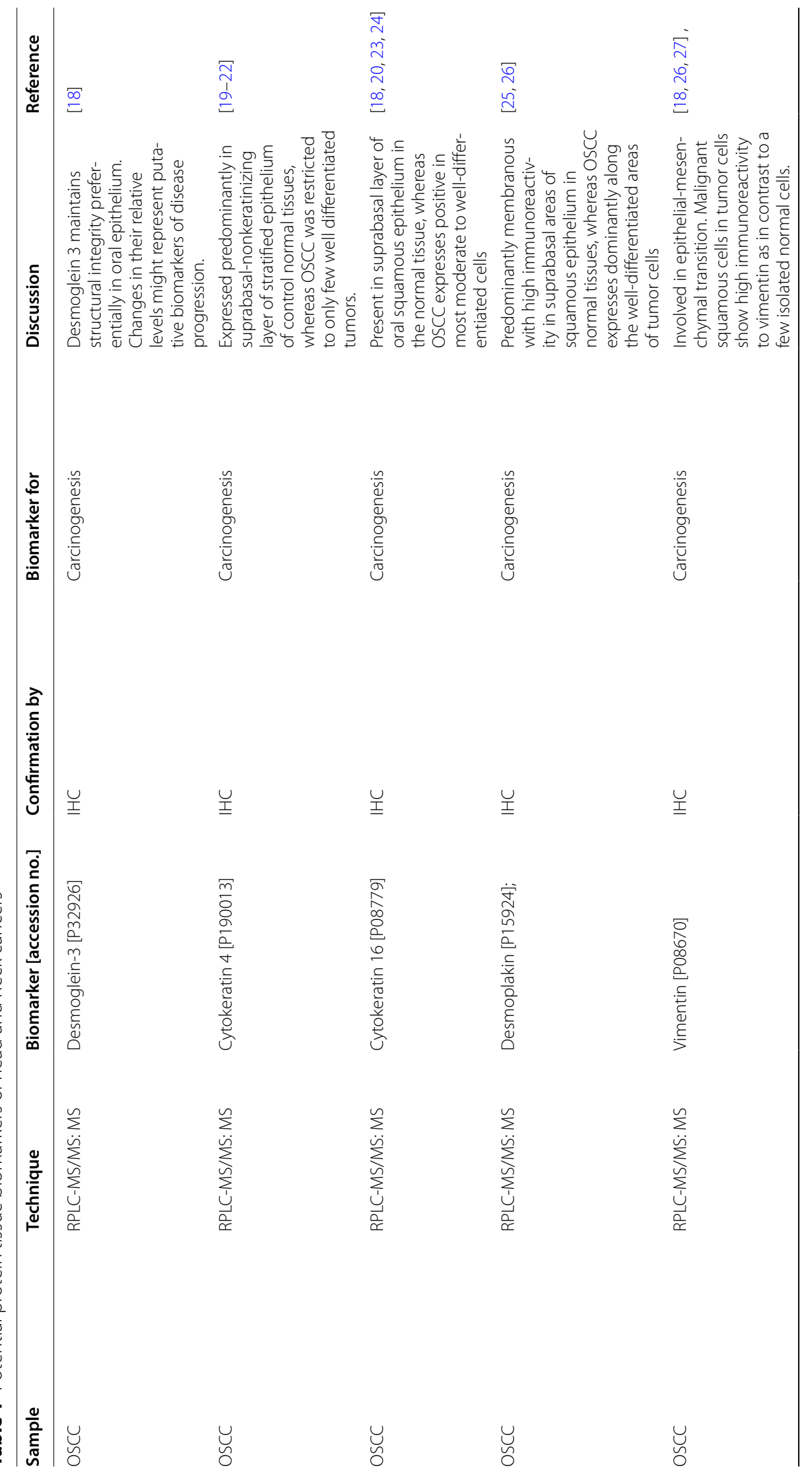




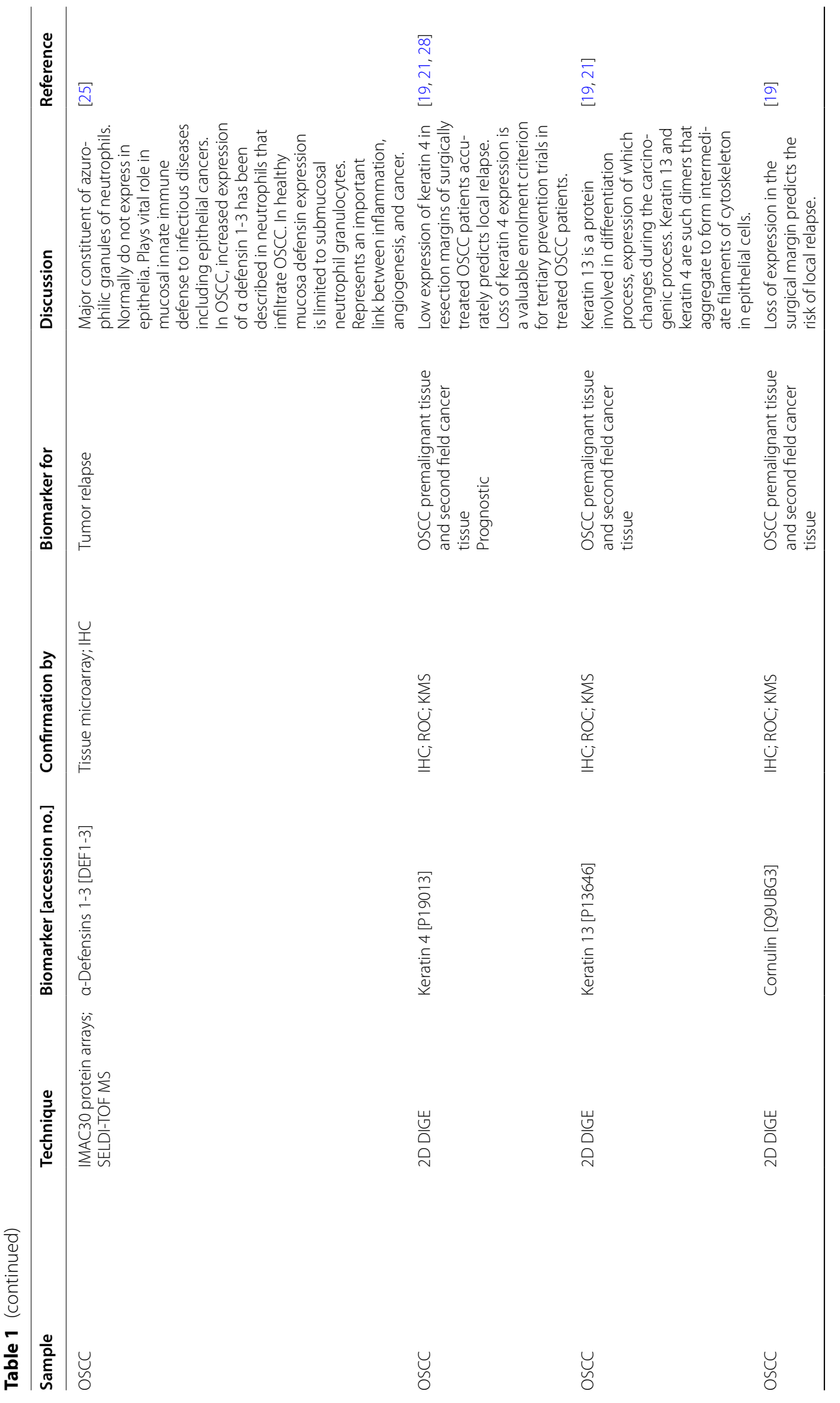




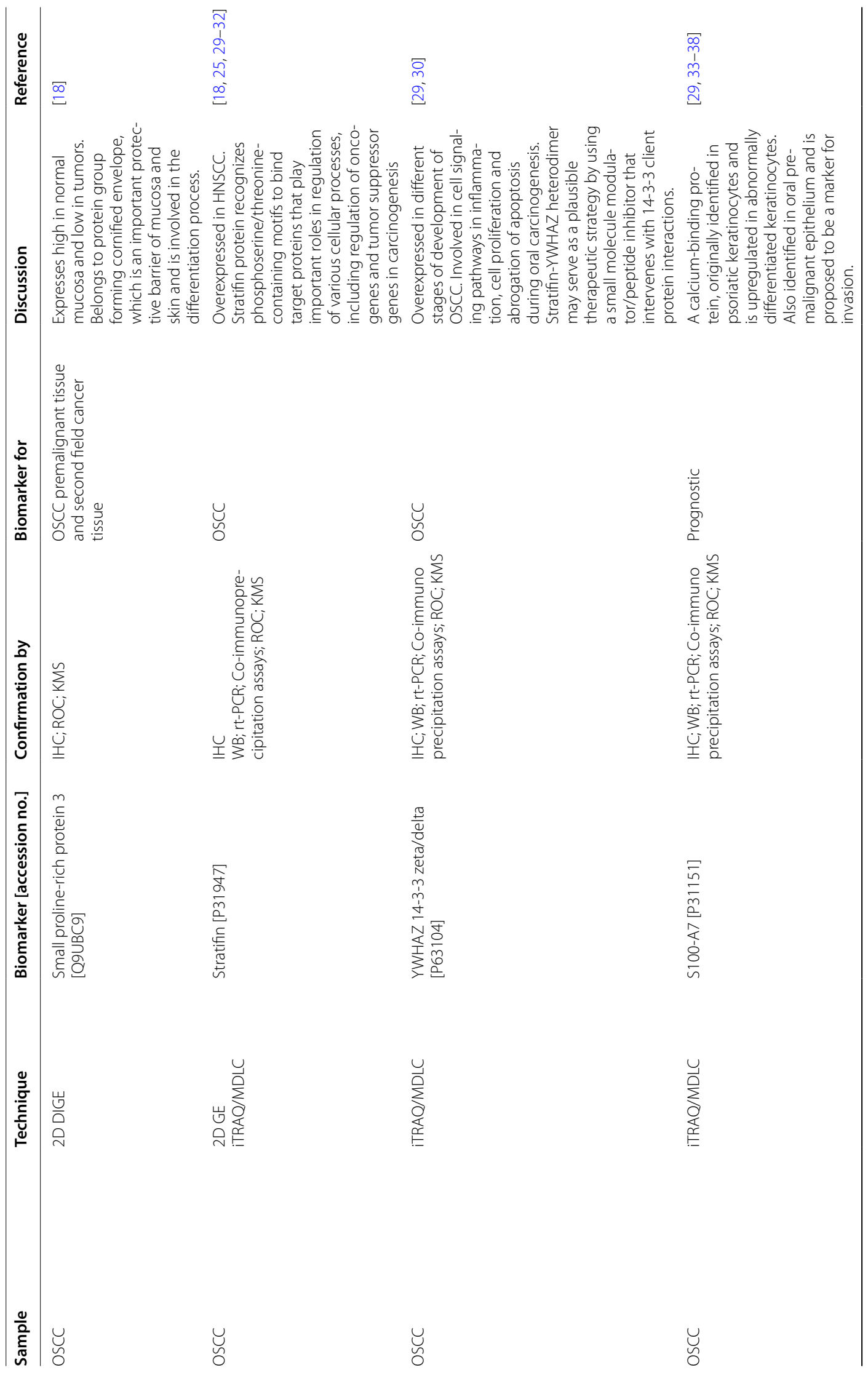




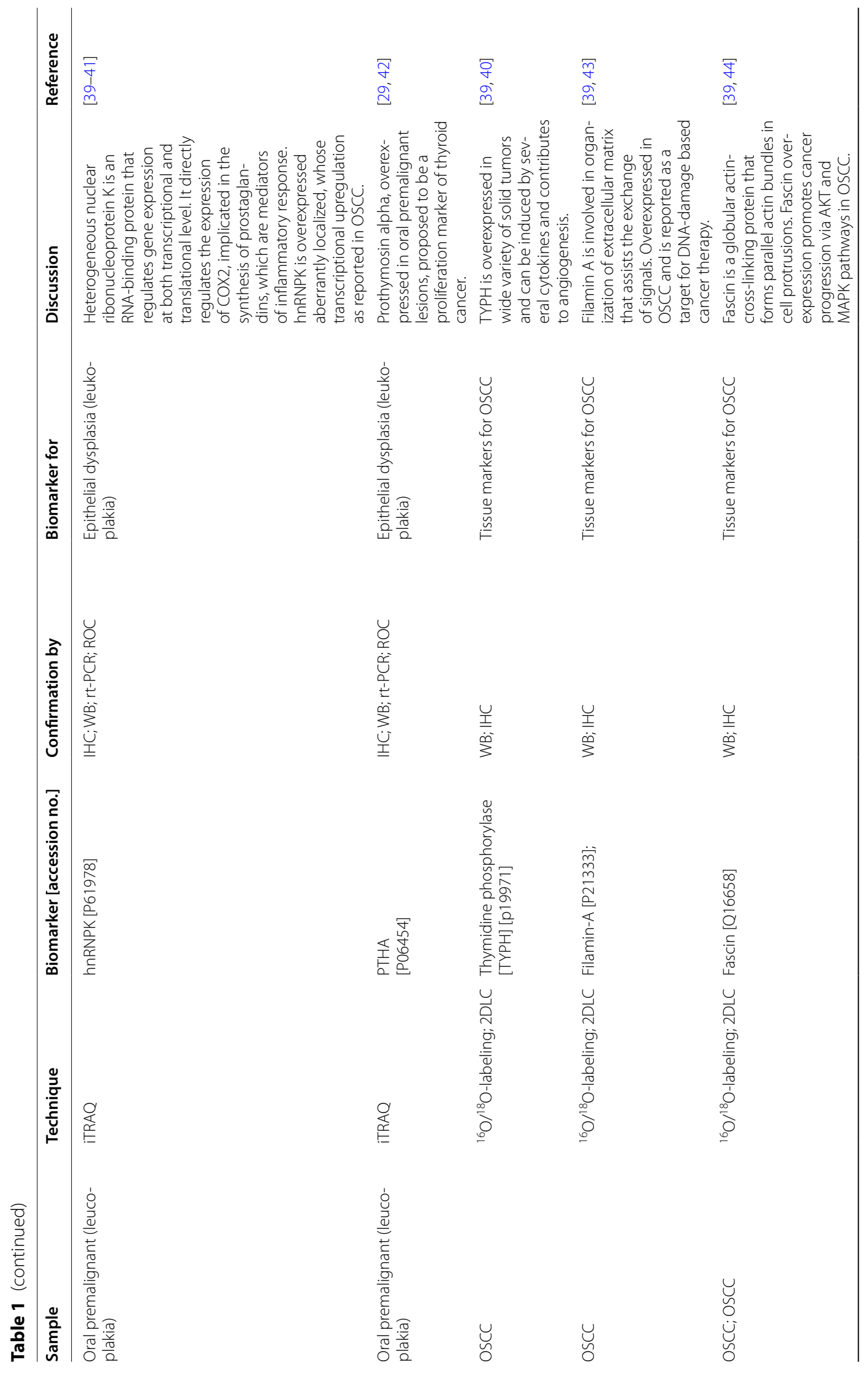


Pillar et al. World J Surg One <wide> <wide>(2021) 19:315

Page 9 of 28

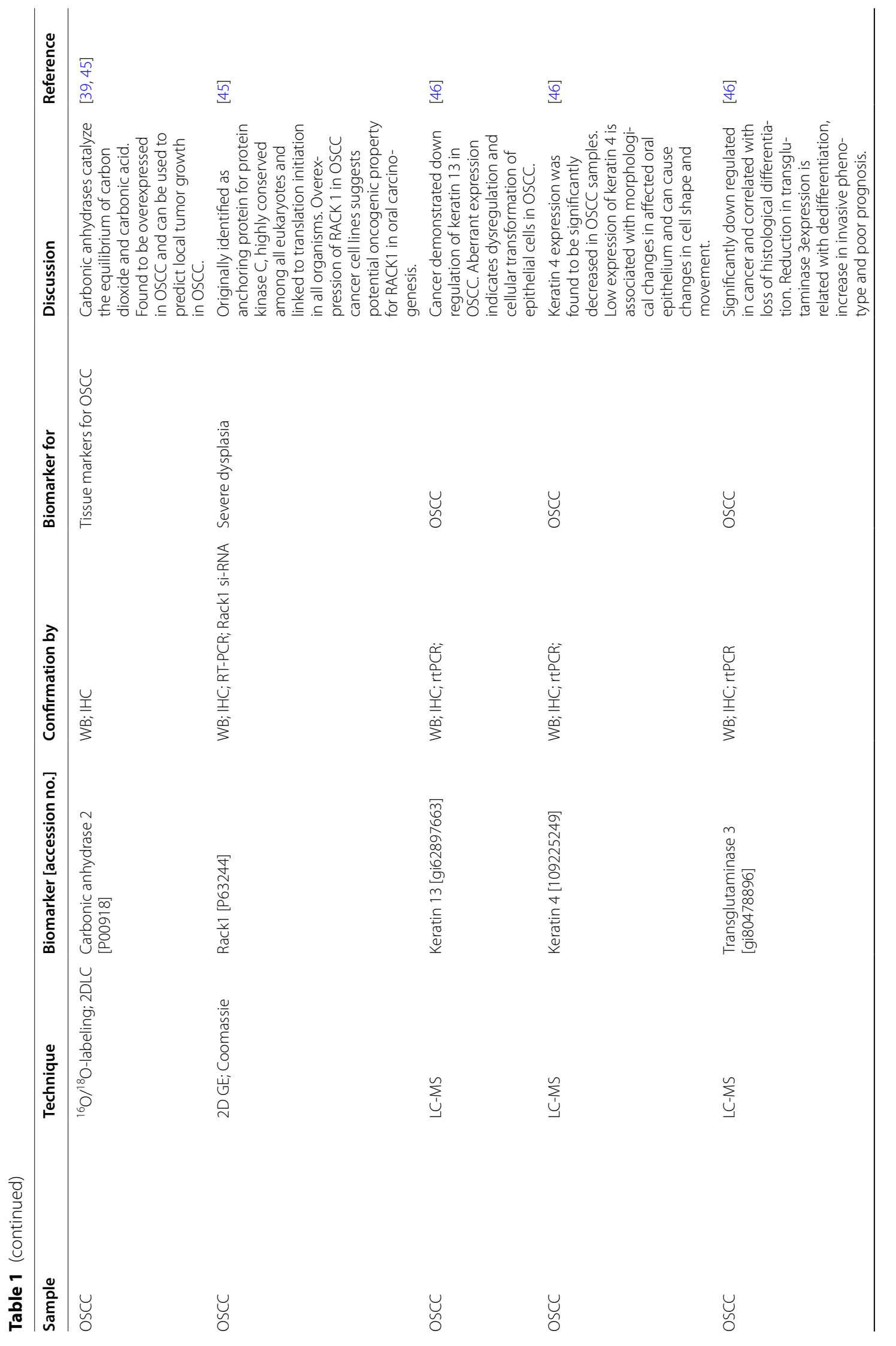




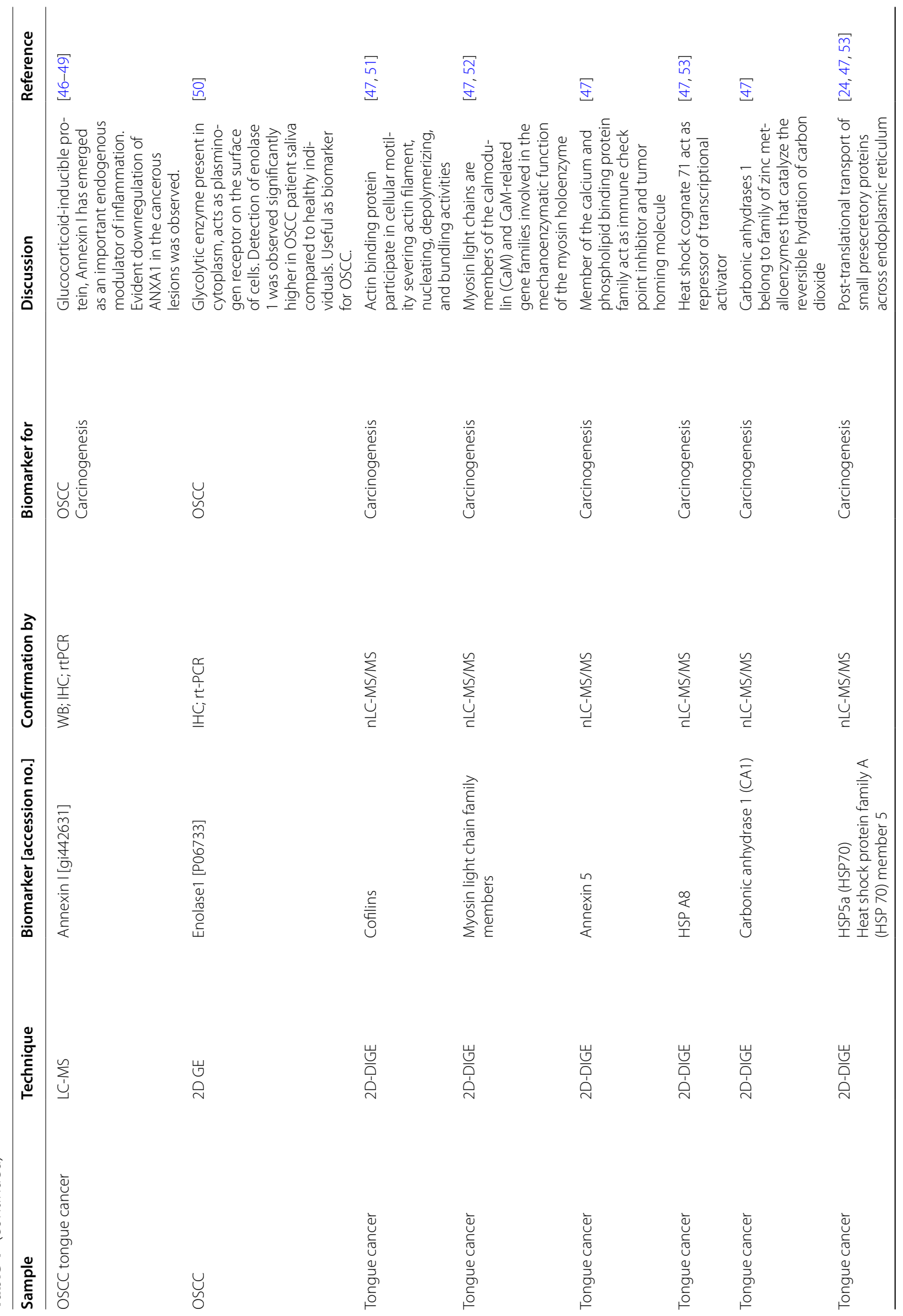


Pillar et al. World J Surg One <wide> <wide>(2021) 19:315

Page 11 of 28

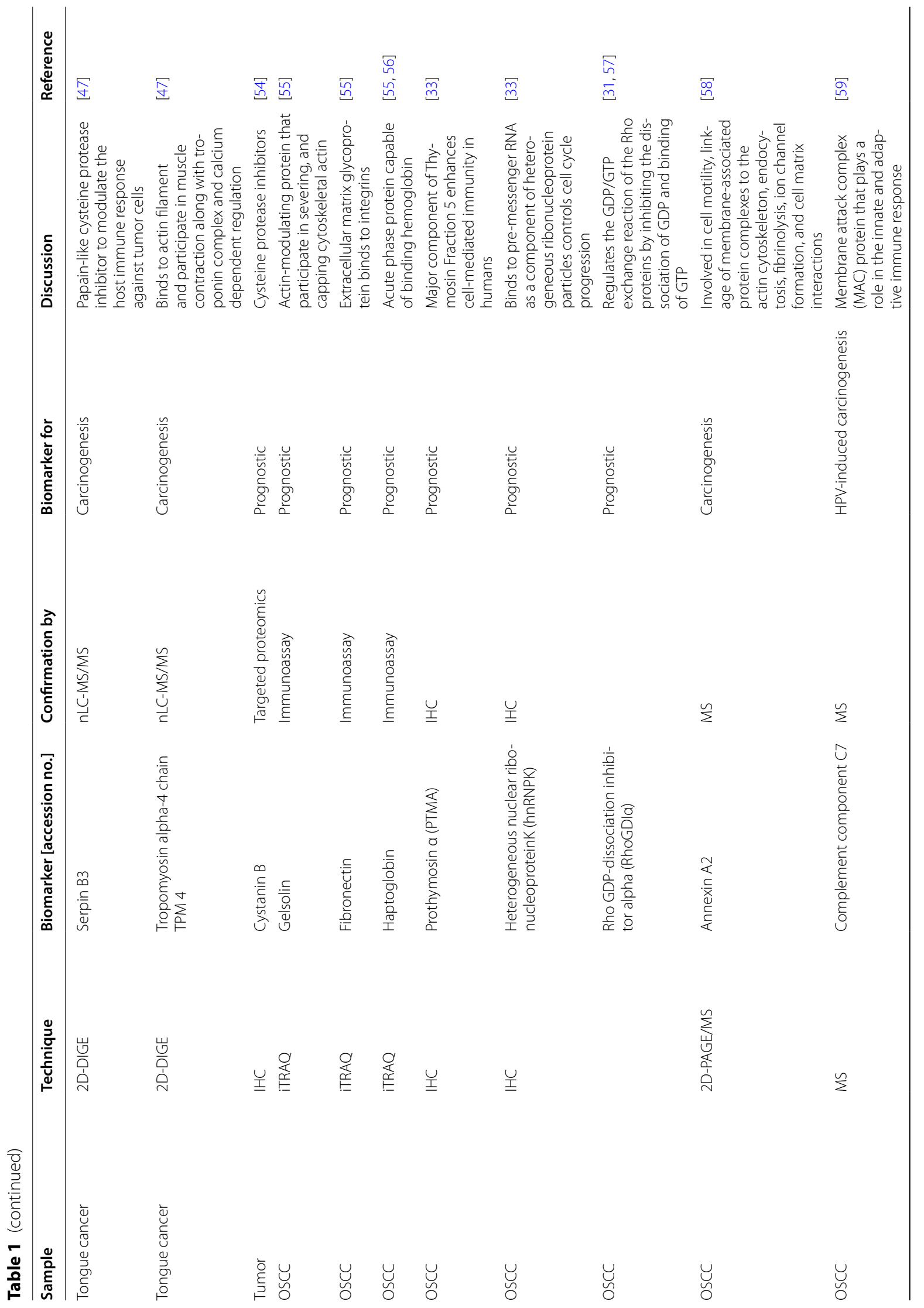




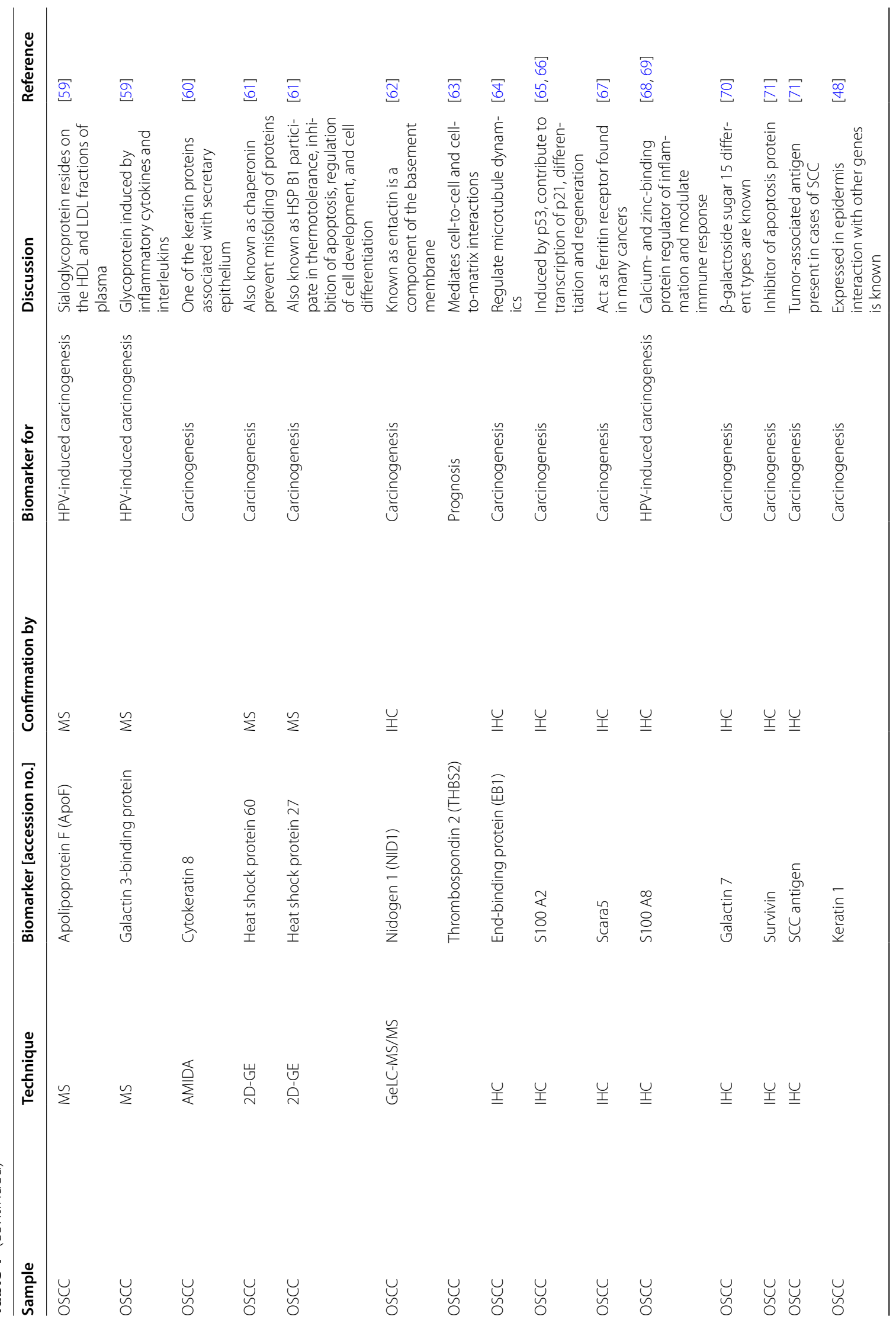




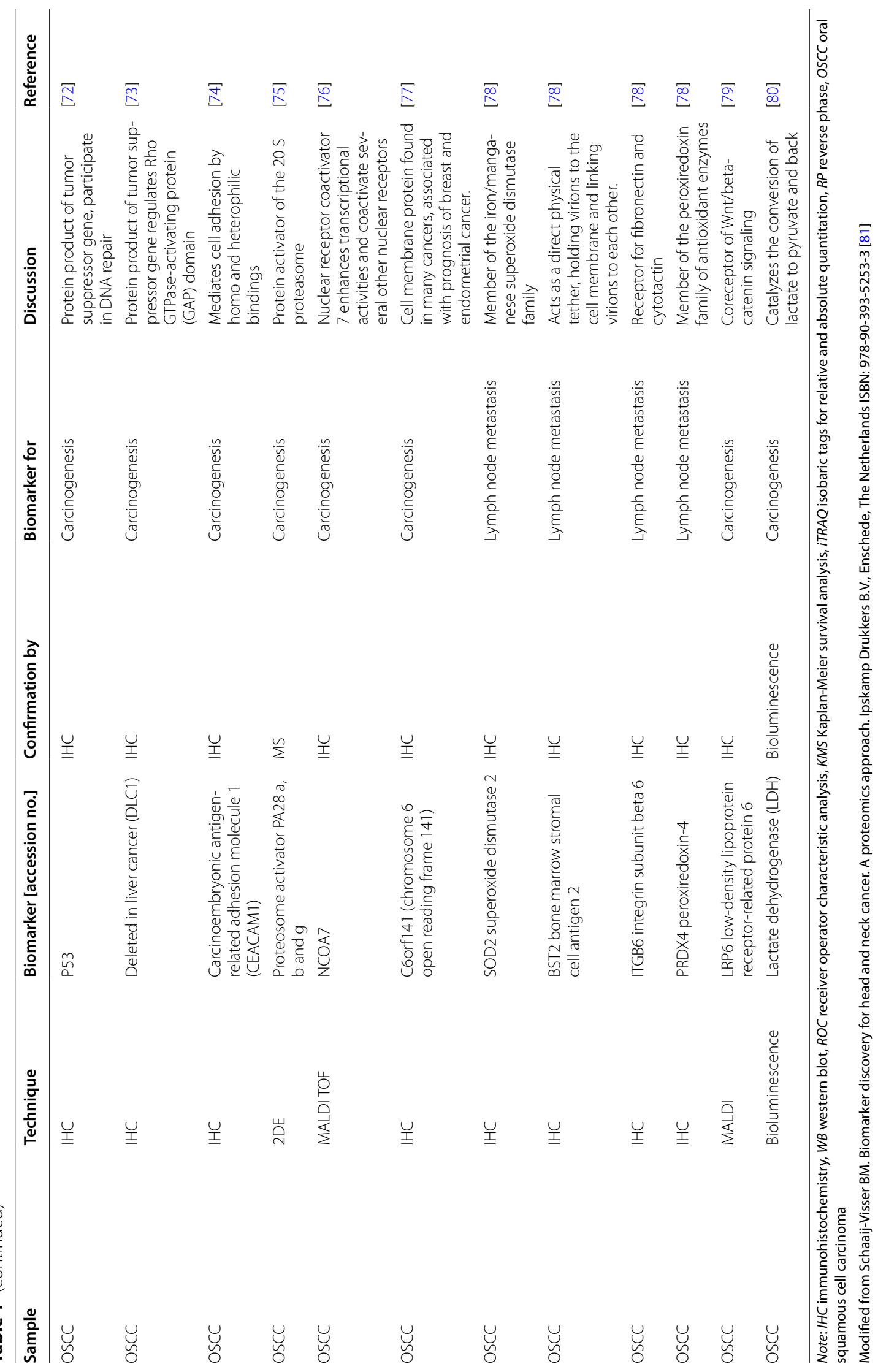




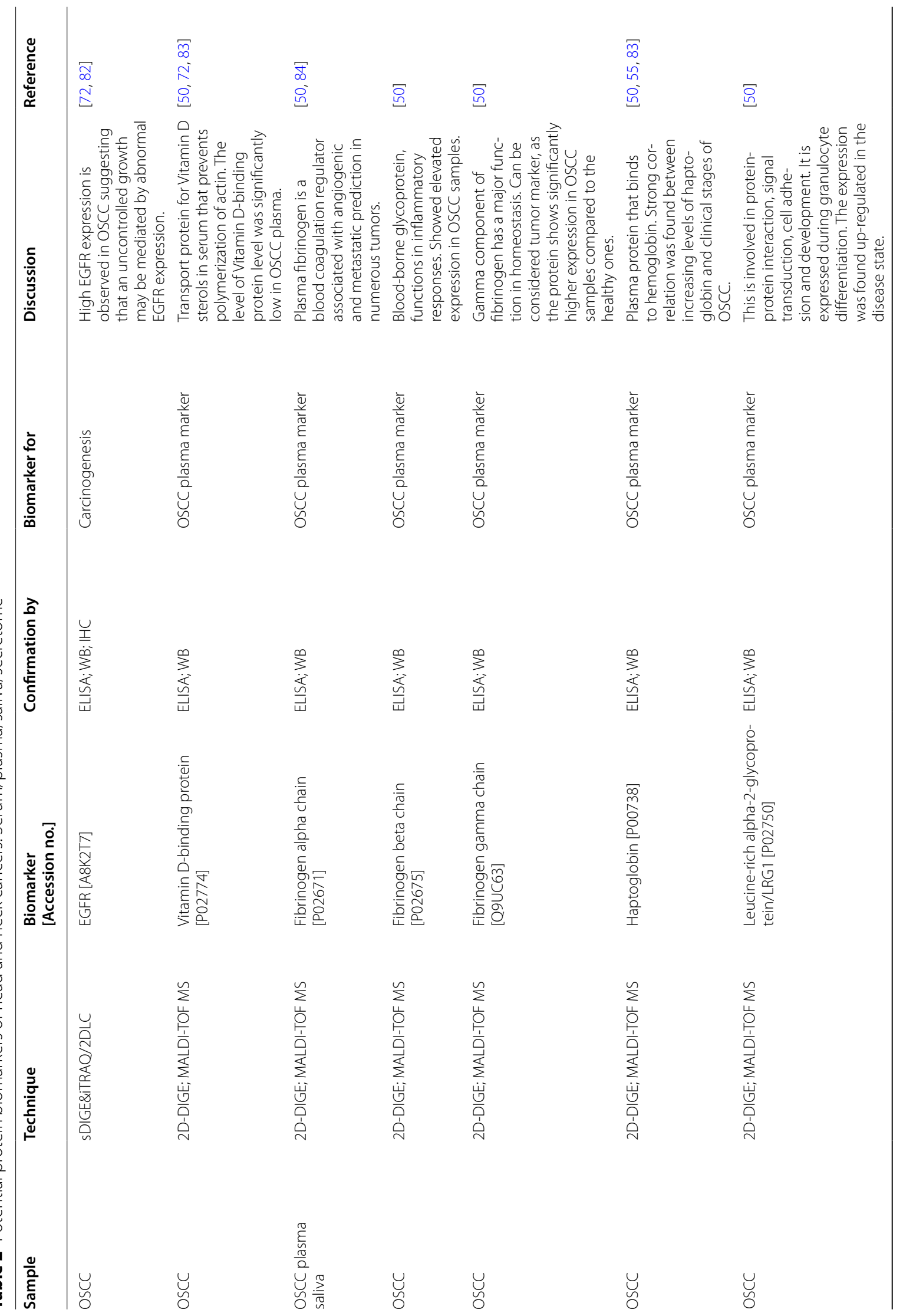




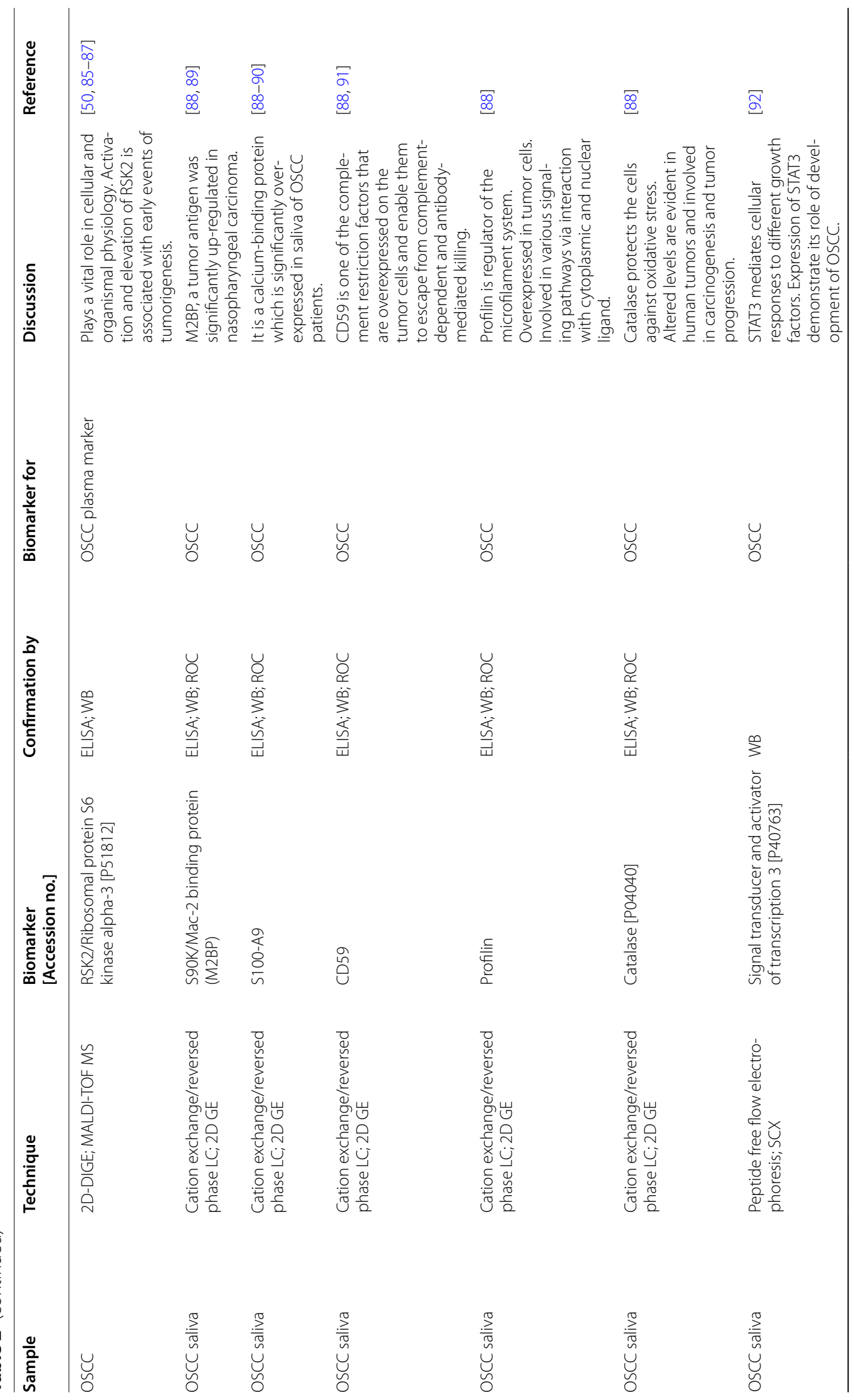




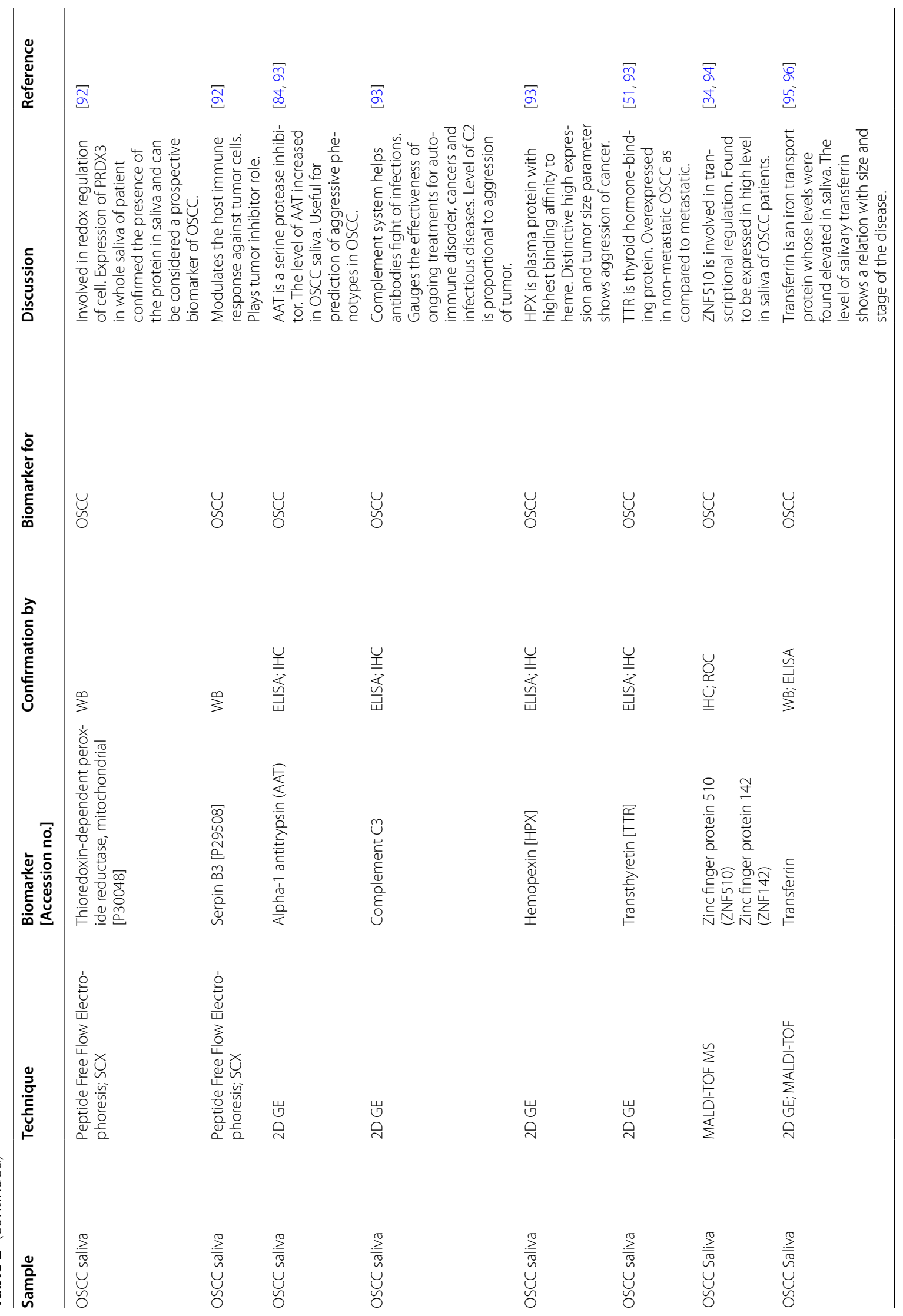


Pillar et al. World J Surg One <wide> <wide>(2021) 19:315

Page 17 of 28

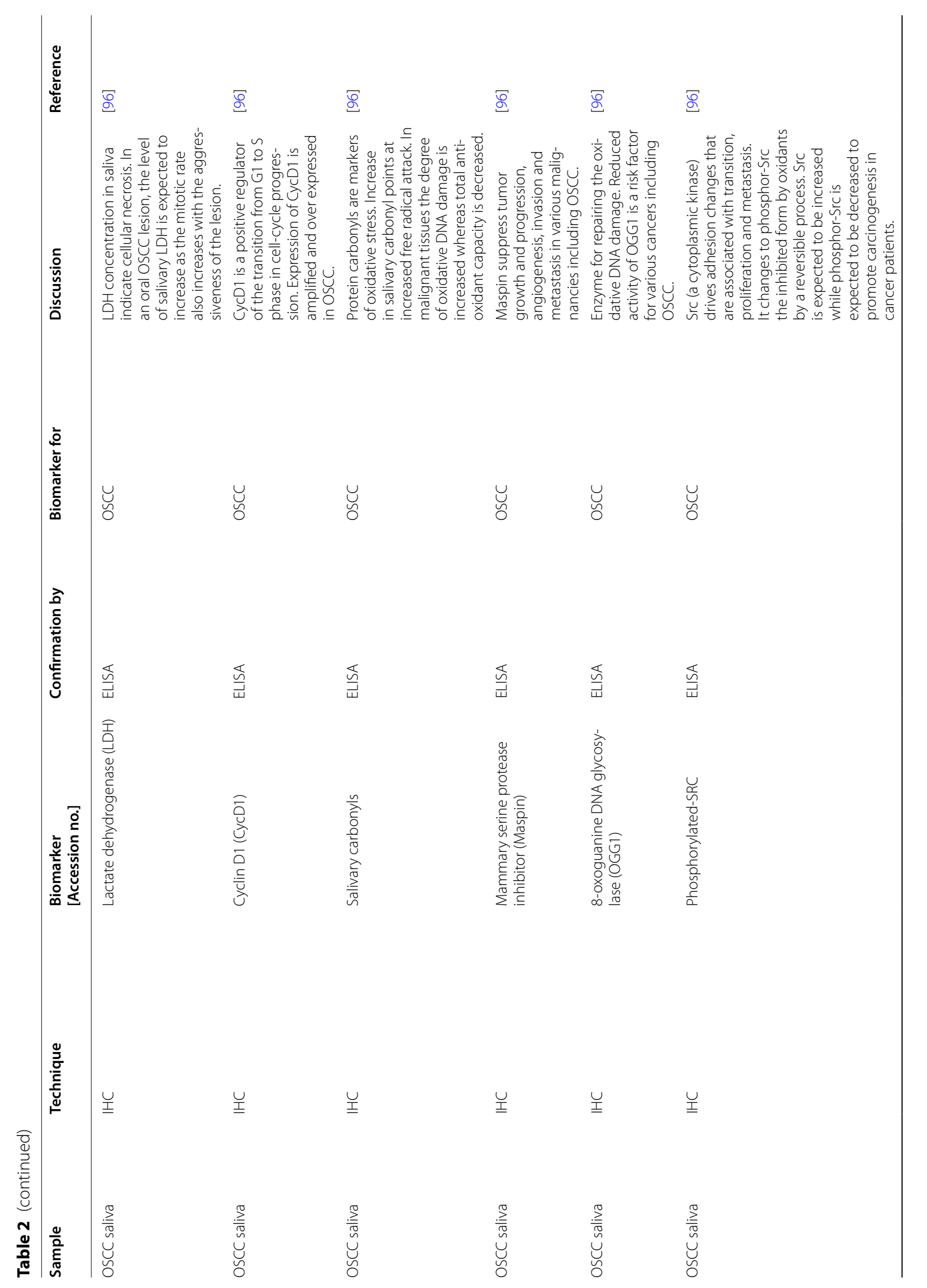




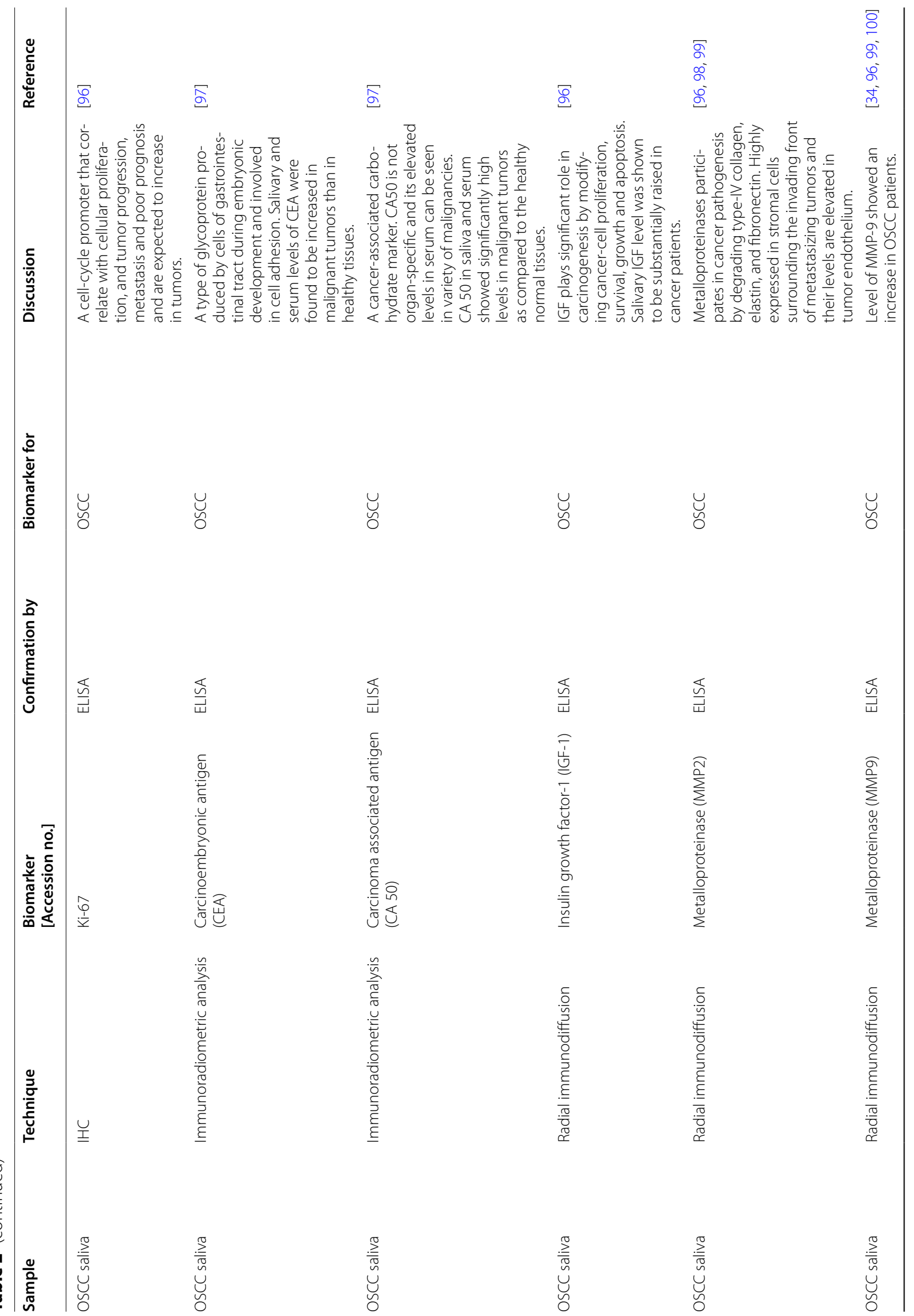




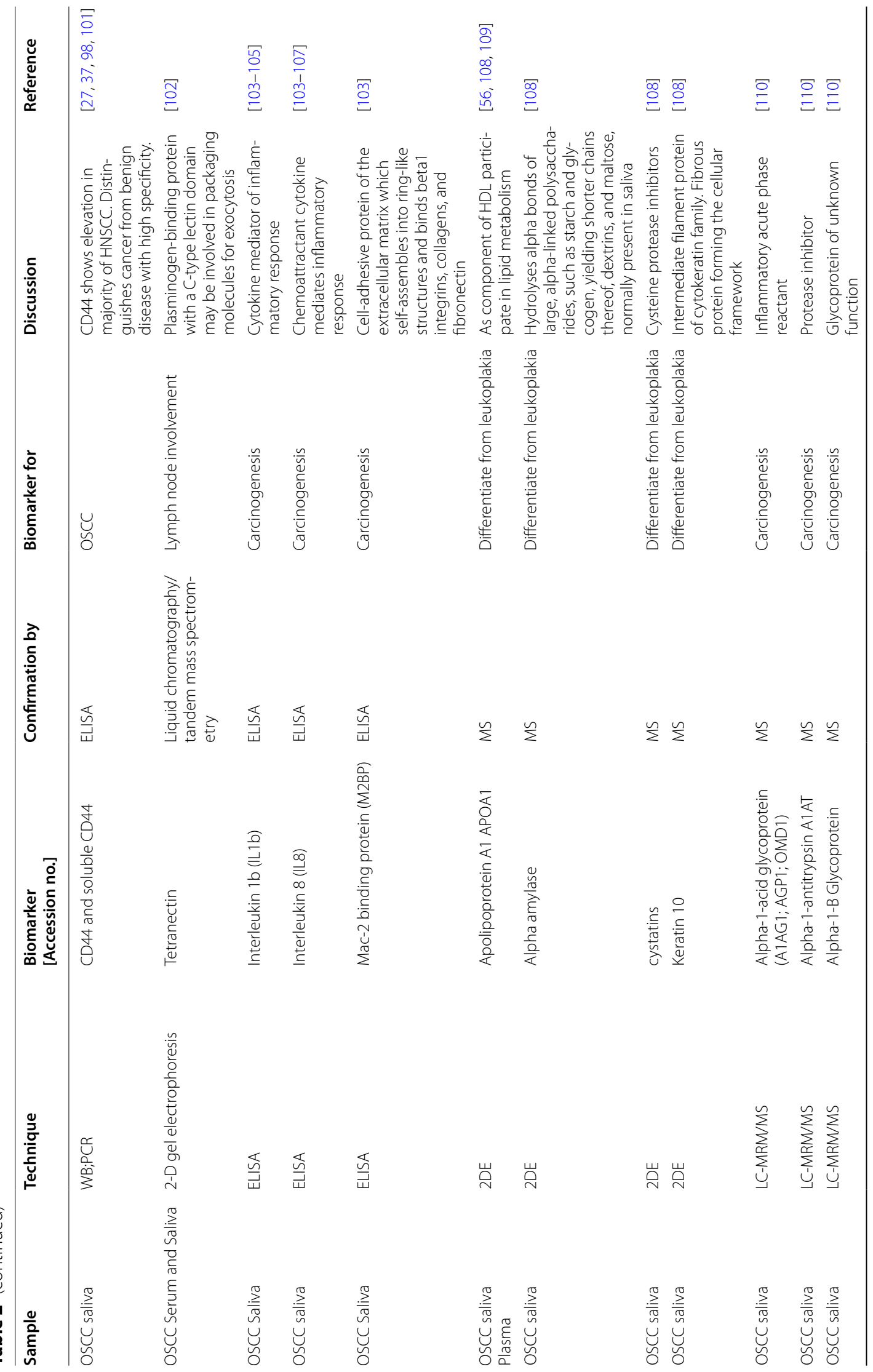



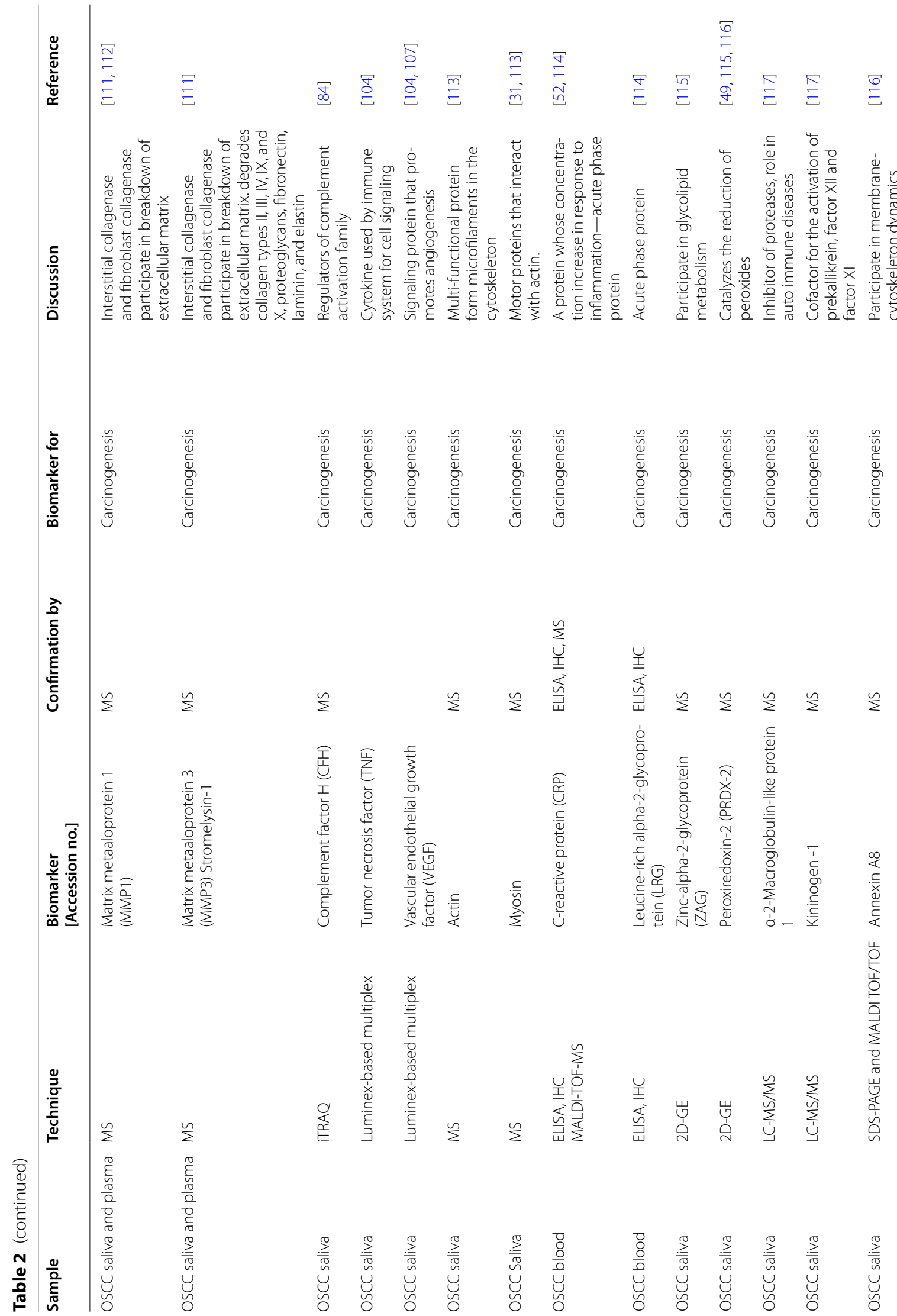

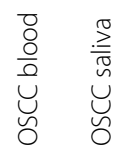

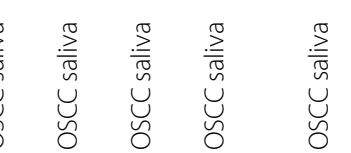




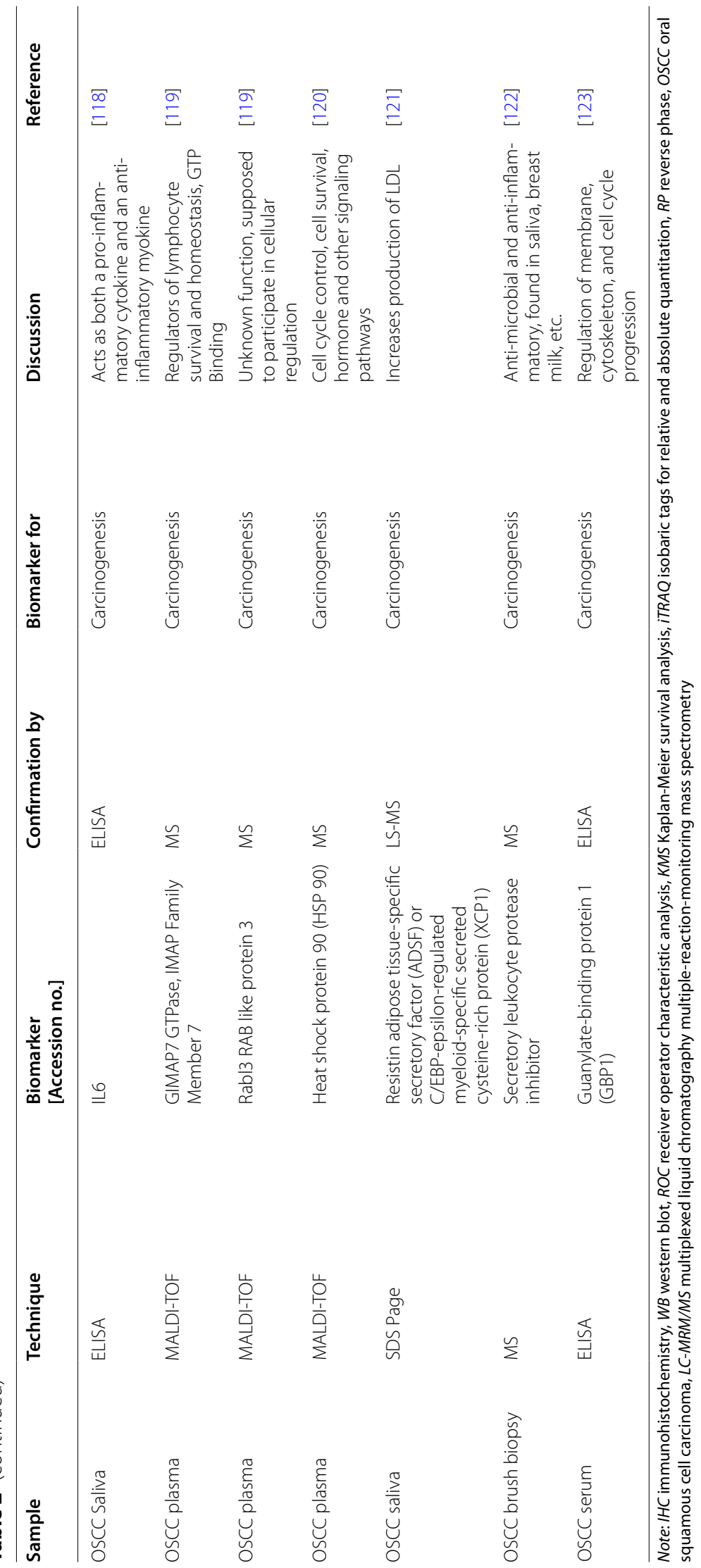


Table 3 Potential protein biomarkers of head and neck cancers: autoantibodies

\begin{tabular}{|c|c|c|c|c|c|c|}
\hline Sample & Technique & Biomarker [accession no.] & Confirmation by & Biomarker for & Discussion & Reference \\
\hline OSCC saliva & $\mathrm{IHC}$ & P53 autoantibody & ELISA; IHC & oscC & $\begin{array}{l}\text { p53 antibodies found only in } \\
\text { serum and saliva of patients } \\
\text { showing overexpression of } \\
\text { p53 in their tumor tissues. } \\
\text { Checks for overexpression of } \\
\text { p53 protein however do not } \\
\text { differentiate between wild } \\
\text { and mutant proteins. }\end{array}$ & [125] \\
\hline oscc & MALDI-TOF/TOF-MS & $\begin{array}{l}\text { Heat shock protein } 70 \\
\text { (HSP70) }\end{array}$ & MS & Carcinogenesis & $\begin{array}{l}\text { Cellular network of molecu- } \\
\text { lar chaperones and folding } \\
\text { catalysts assists in protein } \\
\text { folding process. Identified as } \\
\text { early marker and prognostic } \\
\text { marker in OSCC }\end{array}$ & [126] \\
\hline oscC & MALDI TOF-MS/2DE & Sideroflexin 3 (SFXN3) & MS & Response to therapy & $\begin{array}{l}\text { Mitochondrial serine } \\
\text { transporter participate in } \\
\text { one-carbon metabolism } \\
\text { pathway. }\end{array}$ & [127] \\
\hline
\end{tabular}

Note: IHC immunohistochemistry, WB western blot, ROC receiver operator characteristic analysis, KMS Kaplan-Meier survival analysis, iTRAQ isobaric tags for relative and absolute quantitation, $R P$ reverse phase, $O S C C$ oral squamous cell carcinoma

contact with the harmful components of tobacco-like aromatic polycyclic hydrocarbon (PAH), nitrosamines, aromatic amines, and aldehydes that are responsible for malignant transformation [129]. The metabolism of chemicals occurs in two phases. In phase 1 , reduction and oxidation reactions occur in cytochrome P-450 system, producing reactive and toxic substances. This oxidative stress induces glutathione S-transferase transcription to eliminate the toxic substances [130]. The toxic metabolites produced genetic instability, mutation, and may initiate the carcinogenesis. After the glucuronidation, sulfation, methylation, and conjunction reactions, the toxic agents are inactivated and become hydro soluble, and are excreted [131]. Mutation of $p 53$ have been found to occur more frequently in tobacco and alcohol uses [132], suggesting that inactivation of p53 tumor suppressor gene may play an important role in tobaccoinduced carcinogenesis.

Infection with human papilloma virus (HPV) is another risk factor specially for oropharyngeal cancer. This dsDNA virus has a $7 \mathrm{kB}$ genome with number of early and late genes that synthesize proteins. Only a subset of more than 100 known HPV subtypes are oncogenic and high-risk types. HPVs encodes E6 and E7 oncoproteins that inactivates $\mathrm{p} 53$ and $\mathrm{Rb}$ respectively, leading to failure of tumor suppressor mechanism [133]. Few HPV-associated biomarkers have also been identified.

Association of OSCC with genetic polymorphisms in genes encoding human enzymes related to toxic substance metabolism has also been reported [134] that affects the individual's susceptibility to noxious effects of cancer. Patients with Fanconi anemia (FA) are predisposed to develop OSCC [135]. Fanconi anemia is a recessive genetic disorder caused by biallelic mutation in a member of FA/BRCA pathway [136]. These cancers usually develop at a young age [137]. Another predisposing factor for cancers of hypopharynx is Plumer-Vinson (also called Paterson-Kelly) syndrome, which results from iron-deficiency [138].

Arroyo et al. [139] in a recent meta-analysis found 11 biomarkers of which they did meta-analysis for 4 . Of these, only carcinoembryonic antigens (CEA) and soluble fragment of cytokeratin 19 (CYFRA21) were found to be significantly associated with oral cancer. Kasradze [140] in their review found 44 relevant proteins. Of

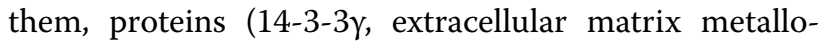
proteinase inducer, and PA28y) were found to be most significant. Other studies reported only the number of proteins differentially expressed without any identification [141-144]. Li et al. [145] identified differential protein expression in oral cancer patients with or without lymph node metastasis. Levels of PF4V1 and F13A1 correlated with number of lymph nodes. Immunoglobulin (Ig) Kappa chain $\mathrm{C}$ region and Isoform 2 of fructose bisphosphate aldolase $\mathrm{A}$ are found to increase in tobacco users; however, these markers are not yet validated [146]. Other investigators found Serpin family of proteins to be overexpressed in tobacco users [147], while some just reported number of proteins with differential expression [148].

The OSCCs occur as a consequence of proto-oncogene activation or tumor suppressor gene inactivation. Promoter hypermethylation is an example of indirect mechanism [149]. The three main alterations in gene function 
that occur in OSCC are (1) inactivation of p53 tumor suppressor gene, (2) inactivation of cyclin- dependant kinase (CDK) inhibitor p16, and (3) overexpression of epidermal growth factor receptor (EGFR); however, mutations in the EGFR genes occur with very low frequencies.

\section{Inactivation of p53 tumor suppressor gene}

p53 has a role in maintaining genomic stability, cellcycle progression, cell differentiation, DNA repair, and apoptosis, and hence is aptly called the "guardian of the genome." Mutations, deletions, and binding with viral proteins can produce p53 dysfunction [150]. It is found in approximately $50 \%$ of OSCC tumors and is one of the most common cancer development events [151] (Fig. 2).
Inactivation of cyclin-dependant kinase (CDK) inhibitor p16

CDK are important molecules responsible for regulation of the cell-cycle. A number of these proteins have been identified and some of these can be targeted.

The function of CDK is regulated by number of genes like p16 and retinoblastoma gene. The effect is brought by regulating the phosphorylation of genes during G1 to $S$ phase, through inhibition of CDK 4 and 6 [152]. The formation of CDK 4-6/cyclin D complex is inhibited by the p16 gene, and p21 gene (Fig. 1) thus leading to cell cycle arrest. Downregulation of these proteins is often associated with OSCC [153]. Regulation of phosphorylation of retinoblastoma gene by $\mathrm{p} 16, \mathrm{p} 21$, Cyclin D, and CDK leads to cell cycle arrest, DNA repair, and apoptosis if repair fails (Fig. 1).

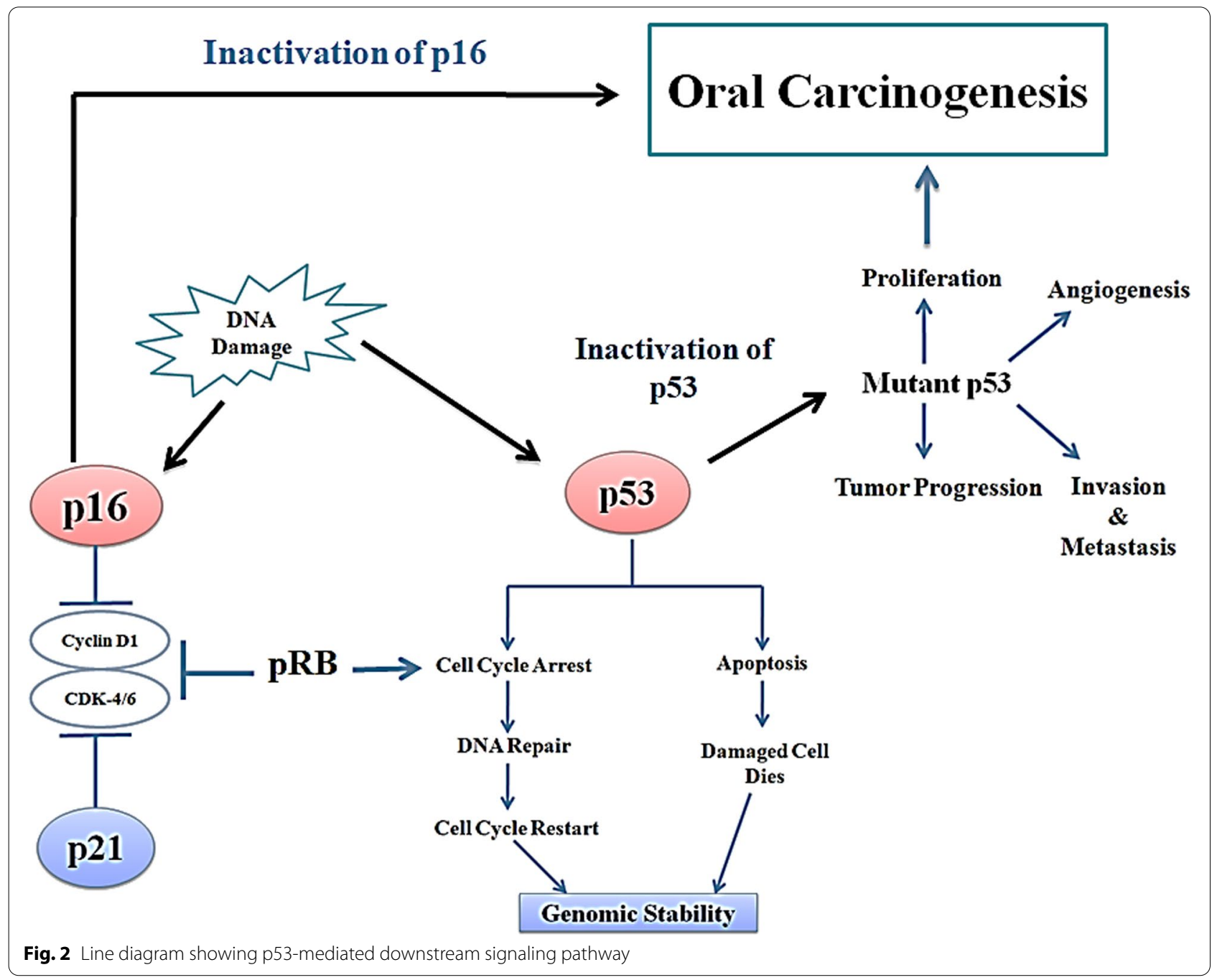




\section{Overexpression of EGFR}

EGFR promotes epidermal cell growth and regulates cell proliferation, while regulation of metastasis and angiogenesis leads to development of OSCC. Therefore, EGFR proteins overexpression leads to increased tumor proliferation. EGFR ligand binding results in a molecular cascade that covers receptor-linked tyrosine kinase activation and other downstream pathways. EGFR family has four types of receptors and can have homo or heterodimers where in two similar members or different members bind to produce a dimer. EGFR controls many pathways however its overexpression is found to be associated with increased carcinogenesis [98, 127, 153, 154]. However, for targeting its mutations are normally looked at and mutant EGFR with chromosome 19-21 mutations are often targeted with tyrosine kinase inhibitors.

The biomarker data presented in the article show that this is still a new field and though a lot of the markers are identified, not much work has been done on validating these so far. Further, the data shows differences in the proteomic profile between continents and also between subsites. There is also a difference between tissue and secretome profile wherein more inflammatory markers are seen in saliva. The validation of diagnostic and prognostic biomarkers is a long-drawn process, and there is a need to have more proteomic research to identify better markers that will improve the diagnosis and prognostication of the patients.

\section{Conclusion}

Proteomic and genomic characterization of tumors is essential for identification of biomarkers of carcinogenesis, therapeutics, prognosis, progression, and metastasis. This is frequently been used in many tumors while their role in others is still under investigation. OSCC is uncommon tumor in the west but is common is South East Asia; hence, very little work is done on it. In recent times, the newer evidence has come that shows $p 53$ and ras mutations to be common, and these tumors have poor prognosis compared to that without it. Further work on proteomics will help identify more markers of carcinogenesis, prognosis, and therapeutic significance and will help identify newer targets.

\section{Supplementary Information}

The online version contains supplementary material available at https://doi. org/10.1186/s12957-021-02423-y.

Additional file 1. Search strategy

\section{Acknowledgements}

None

\section{Authors' contributions}

MP conceived and designed the study and edited the final draft. JP and TC carried out the literature review and prepared the draft manuscript; RD helped in preparing the manuscript and its editing. The authors read and approved the final manuscript.

Funding

None

Availability of data and materials

Not applicable

\section{Declarations}

Ethics approval and consent to participate

Not applicable

Consent for publication

Not applicable

Competing interests

The authors declare that they have no competing interests.

\section{Author details}

${ }^{1}$ Datta Meghe Institute of Medical Sciences, Wardha, India. ${ }^{2}$ Department of Surgical Oncology, Institute of Medical Sciences, Banaras Hindu University, Varanasi 221 005, India.

Received: 3 August 2021 Accepted: 6 October 2021

Published online: 28 October 2021

References

1. Rezende TM, de Souza Freire M, Franco OL. Head and neck cancer: proteomic advances and biomarker achievements. Cancer. 2010;116(21):4914-25.

2. Jemal A, Bray F, Center MM, Ferlay J, Ward E, Forman D. Global cancer statistics. CA Cancer J Clin. 2011;61(2):69-90.

3. Rettig EM, D'Souza G. Epidemiology of head and neck cancer. Surg Oncol Clin N Am. 2015;24(3):379-96.

4. Bettendorf O, Piffkò J, Bànkfalvi A. Prognostic and predictive factors in oral squamous cell cancer: important tools for planning individual therapy? Oral Oncol. 2004;40(2):110-9.

5. Friedman JM, Stavas MJ, Cmelak AJ. Clinical and scientific impact of human papillomavirus on head and neck cancer. World J Clin Oncol. 2014;5(4):781-91.

6. Yuen PW, Man M, Lam KY, Kwong YL. Clinicopathological significance of p16 gene expression in the surgical treatment of head and neck squamous cell carcinomas. J Clin Pathol. 2002;55(1):58-60.

7. Argiris A, Karamouzis MV, Raben D, Ferris RL. Head and neck cancer. Lancet. 2008;371(9625):1695-709.

8. Rifai N, Gillette MA, Carr SA. Protein biomarker discovery and validation: the long and uncertain path to clinical utility. Nat Biotechnol. 2006;24(8):971-83.

9. Hayes DF, Bast RC, Desch CE, Fritsche H Jr, Kemeny NE, Jessup JM, et al. Tumour marker utility grading system: a framework to evaluate clinical utility of tumour markers. J Natl Cancer Inst. 1996;88(20):1456-66.

10. Patel V, Leethanakul C, Gutkind JS. New approaches to the understanding of the molecular basis of oral cancer. Crit Rev Oral Biol Med. 2001;12(1):55-63.

11. Wiseman SM, Stoler DL, Anderson GR. The role of genomic instability in the pathogenesis of squamous cell carcinoma of the head and neck. Surg Oncol Clin N Am. 2004;13(1):1-11.

12. Hu YC, Sidransky D, Ahrendt SA. Molecular detection approaches for smoking associated tumours. Oncogene. 2002;21(48):7289-97.

13. Banks RE, Dunn MJ, Hochstrasser DF, Sanchez JC, Blackstock W, Pappin DJ, et al. Proteomics: new perspectives, new biomedical opportunities. Lancet. 2000;356(9243):1749-56. 
14. Ewing B, Green P. Analysis of expressed sequence tags indicates 35,000 human genes. Nat Genet. 2000;25(2):232-4.

15. Pertea M, Salzberg SL. Between a chicken and a grape: estimating the number of human genes. Genome Biol. 2010;11(5):206.

16. Ludwig JA, Weinstein JN. Biomarkers in cancer staging, prognosis and treatment selection. Nat Rev Cancer. 2005;5(11):845-56.

17. Ralhan R, Desouza LV, Matta A, Tripathi SC, Ghanny S, Datta Gupta S, et al. Discovery and verification of head-and-neck cancer biomarkers by differential protein expression analysis using iTRAQ labeling, multidimensional liquid chromatography, and tandem mass spectrometry. Mol Cell Proteomics. 2008;7(6):1162-73.

18. Patel V, Hood BL, Molinolo AA, Lee NH, Conrads TP, Braisted JC, et al. Proteomic analysis of laser-captured paraffin-embedded tissues: a molecular portrait of head and neck cancer progression. Clin Cancer Res. 2008;14(4):1002-14.

19. Enokida T, Fujii S, Takahashi M, Higuchi Y, Nomura S, Wakasugi T, et al. Gene expression profiling to predict recurrence of advanced squamous cell carcinoma of the tongue: discovery and external validation. Oncotarget. 2017;8(37):61786-99.

20. Fulzele A, Malgundkar SA, Govekar RB, Patil A, Kane SV, Chaturvedi $P$, et al. Proteomic profile of keratins in cancer of the gingivo buccal complex: consolidating insights for clinical applications. J Proteomics. 2013;91:242-58

21. Schaaij-Visser TB, Bremmer JF, Braakhuis BJ, Heck AJ, Slijper M, van der Waal I, et al. Evaluation of cornulin, keratin 4, keratin 13 expression and grade of dysplasia for predicting malignant progression of oral leukoplakia. Oral Oncol. 2010;46(2):123-7.

22. Wang R, Yuan Y, Zhou Y, Zhang D, Zhang L, Zeng X, et al. Screening diagnostic biomarkers of OSCC via an LCM-based proteomic approach. Oncol Rep. 2018;40(4):2088-96.

23. Safadi RA, Abdullah NI, Alaaraj RF, Bader DH, Divakar DD, Hamasha AA, et al. Clinical and histopathologic prognostic implications of the expression of cytokeratins $8,10,13,14,16,18$ and 19 in oral and oropharyngeal squamous cell carcinoma. Arch Oral Biol. 2019;99:1-8.

24. Thiel UJ, Feltens R, Adryan B, Gieringer R, Brochhausen C, Schuon R, et al. Analysis of differentially expressed proteins in oral squamous cell carcinoma by MALDI-TOF MS. J Oral Pathol Med. 2011;40(5):369-79.

25. Roesch-Ely M, Nees M, Karsai S, Ruess A, Bogumil R, Warnken U, et al. Proteomic analysis reveals successive aberrations in protein expression from healthy mucosa to invasive head and neck cancer. Oncogene. 2007:26(1):54-64.

26. Hoffmann F, Umbreit C, Krüger T, Pelzel D, Ernst G, Kniemeyer O, et al. Identification of proteomic markers in head and neck cancer using MALDI-MS imaging, LC-MS/MS, and immunohistochemistry. Proteomics Clin Appl. 2019;13(1):e1700173.

27. Irani S, Dehghan A. The expression and functional significance of vascular endothelial-cadherin, CD44, and vimentin in oral squamous cell carcinoma. J Int Soc Prev Community Dent. 2018;8(2):110-7.

28. Schaaij-Visser TB, Graveland AP, Gauci S, Braakhuis BJ, Buijze M, Heck AJ, et al. Differential proteomics identifies protein biomarkers that predict local relapse of head and neck squamous cell carcinomas. Clin Cancer Res. 2009;15(24):7666-75.

29. Ralhan R, Desouza LV, Matta A, Tripathi SC, Ghanny S, Dattagupta S, et al. iTRAQ-multidimensional liquid chromatography and tandem mass spectrometry-based identification of potential biomarkers of oral epithelial dysplasia and novel networks between inflammation and premalignancy. J Proteome Res. 2009;8(1):300-9.

30. Ralhan R, Masui O, Desouza LV, Matta A, Macha M, Siu KW. Identification of proteins secreted by head and neck cancer cell lines using LC-MS/MS: strategy for discovery of candidate serological biomarkers. Proteomics. 2011;11(12):2363-76.

31. Lo WY, Tsai MH, Tsai Y, Hua CH, Tsai FJ, Huang SY, et al. Identification of over-expressed proteins in oral squamous cell carcinoma (OSCC) patients by clinical proteomic analysis. Clin Chim Acta. 2007;376(1-2):101-7.

32. Matta A, DeSouza LV, Shukla NK, Gupta SD, Ralhan R, Siu KW. Prognostic significance of head-and-neck cancer biomarkers previously discovered and identified using iTRAQ-labeling and multidimensional liquid chromatography-tandem mass spectrometry. J Proteome Res. 2008; (5):2078-87.
33. Chauhan SS, Kaur J, Kumar M, Matta A, Srivastava G, Alyass A, et al. Prediction of recurrence-free survival using a protein expression-based risk classifier for head and neck cancer. Oncogenesis. 2015;4(4):e147.

34. Dey KK, Pal I, Bharti R, Dey G, Kumar BN, Rajput S, et al. Identification of RAB2A and PRDX1 as the potential biomarkers for oral squamous cell carcinoma using mass spectrometry-based comparative proteomic approach. Tumour Biol. 2015;36(12):9829-37.

35. Kaur J, Matta A, Kak I, Srivastava G, Assi J, Leong I, et al. S100A7 overexpression is a predictive marker for high risk of malignant transformation in oral dysplasia. Int J Cancer. 2014;134(6):1379-88.

36. Kesting MR, Sudhoff H, Hasler RJ, Nieberler M, Pautke C, Wolff KD, et al. Psoriasin (S100A7) up-regulation in oral squamous cell carcinoma and its relation to clinicopathologic features. Oral Oncol. 2009:45(8):731-6.

37. Sivadasan P, Gupta MK, Sathe G, Sudheendra HV, Sunny SP, Renu D, et al. Salivary proteins from dysplastic leukoplakia and oral squamous cell carcinoma and their potential for early detection. J Proteomics. 2020;212:103574.

38. Tripathi SC, Matta A, Kaur J, Grigull J, Chauhan SS, Thakar A, et al. Nuclear S100A7 is associated with poor prognosis in head and neck cancer. PLoS One. 2010;5(8):e11939.

39. Chi LM, Lee CW, Chang KP, Hao SP, Lee HM, Liang Y, et al. Enhanced interferon signaling pathway in oral cancer revealed by quantitative proteome analysis of microdissected specimens using 160/180 labeling and integrated two-dimensional LC-ESI-MALDI tandem MS. Mol Cell Proteomics. 2009:8(7):1453-74.

40. Wu CS, Chang KP, Chen LC, Chen CC, Liang Y, Hseuh C, et al. Heterogeneous ribonucleoprotein $\mathrm{K}$ and thymidine phosphorylase are independent prognostic and therapeutic markers for oral squamous cell carcinoma. Oral Oncol. 2012;48(6):516-22.

41. Matta A, Tripathi SC, DeSouza LV, Grigull J, Kaur J, Chauhan SS, et al. Heterogeneous ribonucleoprotein $\mathrm{K}$ is a marker of oral leukoplakia and correlates with poor prognosis of squamous cell carcinoma. Int J Cancer. 2009;125(6):1398-406.

42. Tripathi SC, Matta A, Kaur J, Grigull J, Chauhan SS, Thakar A, et al. Overexpression of prothymosin alpha predicts poor disease outcome in head and neck cancer. PLoS One. 2011;6(5):e19213.

43. Liu W, Zeng L, Li N, Wang F, Jiang C, Guo F, et al. Quantitative proteomic analysis for novel biomarkers of buccal squamous cell carcinoma arising in background of oral submucous fibrosis. BMC Cancer. 2016;16:584

44. Rodrigues PC, Sawazaki-Calone I, Ervolino de Oliveira C, Soares Macedo CC, Dourado MR, Cervigne NK, et al. Fascin promotes migration and invasion and is a prognostic marker for oral squamous cell carcinoma. Oncotarget. 2017;8(43):74736-54.

45. Wang Z, Jiang L, Huang C, Li Z, Chen L, Gou L, et al. Comparative proteomics approach to screening of potential diagnostic and therapeutic targets for oral squamous cell carcinoma. Mol Cell Proteomics. 2008;7(9):1639-50.

46. Negishi A, Masuda M, Ono M, Honda K, Shitashige M, Satow R, et al. Quantitative proteomics using formalin-fixed paraffin-embedded tissues of oral squamous cell carcinoma. Cancer Sci. 2009;100(9):1605-11.

47. Ananthi S, Lakshmi CNP, Atmika P, Anbarasu K, Mahalingam S. Global quantitative proteomics reveal deregulation of cytoskeletal and apoptotic signalling proteins in oral tongue squamous cell carcinoma. Sci Rep. 2018;8(1):1567.

48. Roman E, Lunde ML, Miron T, Warnakulasauriya S, Johannessen $A C$, Vasstrand EN, et al. Analysis of protein expression profile of oral squamous cell carcinoma by MALDI-TOF-MS. Anticancer Res. 2013:33(3):837-45.

49. Szanto I, Mark L, Bona A, Maasz G, Sandor B, Gelencser G, et al. Highthroughput screening of saliva for early detection of oral cancer: a pilot study. Technol Cancer Res Treat. 2012;11(2):181-8.

50. Katakura A, Yamamoto N, Sakuma T, Sugahara K, Onda T, Noguchi S, et al. A screening test for oral cancer using saliva samples: proteomic analysis of biomarkers in whole saliva. J Oral Maxillofac Surg Med Pathol. 2015;27(1):1-5

51. Dowling P, Wormald R, Meleady P, Henry M, Curran A, Clynes M. Analysis of the saliva proteome from patients with head and neck squamous cell carcinoma reveals differences in abundance levels of proteins associated with tumour progression and metastasis. J Proteomics. 2008;71(2):168-75. 
52. Turhani D, Krapfenbauer K, Thurnher D, Langen H, Fountoulakis M. Identification of differentially expressed, tumour-associated proteins in oral squamous cell carcinoma by proteomic analysis. Electrophoresis. 2006;27(7):1417-23.

53. Chanthammachat P, Promwikorn W, Pruegsanusak K, Roytrakul S, Srisomsap C, Chokchaichamnankit D, et al. Comparative proteomic analysis of oral squamous cell carcinoma and adjacent non-tumour tissue from Thailand. Arch Oral Biol. 2013;58(11):1677-85.

54. Carnielli CM, Macedo CCS, De Rossi T, Granato DC, Rivera C, Domingues RR, et al. Combining discovery and targeted proteomics reveals a prognostic signature in oral cancer. Nat Commun. 2018;9(1):3598,

55. Chai YD, Zhang L, Yang Y, Su T, Charugundla P, Ai J, et al. Discovery of potential serum protein biomarkers for lymph node metastasis in oral cancer. Head Neck. 2016;38(1):118-25.

56. Chang SC, Lin WL, Chang YF, Lee CT, Wu JS, Hsu PH, et al. Glycoproteomic identification of novel plasma biomarkers for oral cancer. J Food Drug Anal. 2019;27(2):483-93.

57. Chiang WF, Ho HC, Chang HY, Chiu CC, Chen YL, Hour TC, et al. Overexpression of Rho GDP-dissociation inhibitor alpha predicts poor survival in oral squamous cell carcinoma. Oral Oncol. 2011:47(6):452-8.

58. Cristofaro MG, Scumaci D, Fiumara CV, Di Sanzo M, Zuccalà V, Donato G, et al. Identification of prognosis-related proteins in gingival squamous cell carcinoma by twodimensional gel electrophoresis and mass spectrometry-based proteomics. Ann Ital Chir. 2014;85(6):518-24.

59. Dickinson A, Saraswat M, Syrjänen S, Tohmola T, Silén R, Randén-Brady $\mathrm{R}$, et al. Comparing serum protein levels can aid in differentiating HPV-negative and -positive oropharyngeal squamous cell carcinoma patients. PLoS One. 2020;15(6):e0233974

60. Gires O, Mack B, Rauch J, Matthias C. CK8 correlates with malignancy in leukoplakia and carcinomas of the head and neck. Biochem Biophys Res Commun. 2006:343(1):252-9.

61. He QY, Chen J, Kung HF, Yuen AP, Chiu JF. Identification of tumour-associated proteins in oral tongue squamous cell carcinoma by proteomics. Proteomics. 2004;4(1):271-8.

62. Hsu CW, Chang KP, Huang Y, Liu HP, Hsueh PC, Gu PW, et al. Proteomic profiling of paired interstitial fluids reveals dysregulated pathways and salivary NID1 as a biomarker of oral cavity squamous cell carcinoma. Mol Cell Proteomics. 2019;18(10):1939-49.

63. Hsu CW, Yu JS, Peng PH, Liu SC, Chang YS, Chang KP, et al. Secretome profiling of primary cells reveals that THBS2 is a salivary biomarker of oral cavity squamous cell carcinoma. J Proteome Res. 2014;13(11):4796-807.

64. Kumar M, Mehra S, Thakar A, Shukla NK, Roychoudhary A, Sharma MC, et al. End binding 1 (EB1) overexpression in oral lesions and cancer: a biomarker of tumour progression and poor prognosis. Clin Chim Acta. 2016:459:45-52.

65. Kumar M, Srivastava G, Kaur J, Assi J, Alyass A, Leong I, et al. Prognostic significance of cytoplasmic S100A2 overexpression in oral cancer patients. J Transl Med. 2015;13:8.

66. Shan J, Sun Z, Yang J, Xu J, Shi W, Wu Y, et al. Discovery and preclinical validation of proteomic biomarkers in saliva for early detection of oral squamous cell carcinomas. Oral Dis. 2019;25(1):97-107.

67. Liu Y, Tan YR, Sun WW, Ju WT, Fu Y, Wang LZ, et al. Identification of SCARA5 as a potential biomarker for oral squamous cell carcinoma using MALDI-TOF-MS analysis. Proteomics Clin Appl. 2018;12(5):e1700180.

68. Lo WY, Lai CC, Hua CH, Tsai MH, Huang SY, Tsai CH, et al. S100A8 is identified as a biomarker of HPV18-infected oral squamous cell carcinomas by suppression subtraction hybridization, clinical proteomics analysis, and immunohistochemistry staining. J Proteome Res. 2007;6(6):2143-51.

69. Xiao H, Langerman A, Zhang Y, Khalid O, Hu S, Cao CX, et al. Quantitative proteomic analysis of microdissected oral epithelium for cancer biomarker discovery. Oral Oncol. 2015;51(11):1011-9.

70. Matsukawa S, Morita K, Negishi A, Harada H, Nakajima Y, Shimamoto $\mathrm{H}$, et al. Galectin-7 as a potential predictive marker of chemo- and/or radio-therapy resistance in oral squamous cell carcinoma. Cancer Med. 2014;3(2):349-61.

71. Oluwadara O, Giacomelli L, Christensen R, Kossan G, Avezova R, Chiappelli F. LCK, survivin and PI-3K in the molecular biomarker profiling of oral lichen planus and oral squamous cell carcinoma. Bioinformation. 2009;4(6):249-57.

72. Świątkowski W, Rahnama M, Tomaszewski T, Bigas M, Świątkowska A, Łobacz M, et al. Association between clinical stage of oral cancer and expression of immunohistochemical markers. Pol Przegl Chir. 2017;89(6):17-22.

73. Tripathi SC, Kaur J, Matta A, Gao X, Sun B, Chauhan SS, et al. Loss of DLC1 is an independent prognostic factor in patients with oral squamous cell carcinoma. Mod Pathol. 2012;25(1):14-25.

74. Wang FF, Guan BX, Yang JY, Wang HT, Zhou CJ. CEACAM1 is overeXpressed in oral tumours and related to tumourigenesis. Med Mol Morphol. 2017;50(1):42-51.

75. Wang Z, Feng X, Liu X, Jiang L, Zeng X, Ji N, et al. Involvement of potential pathways in malignant transformation from oral leukoplakia to oral squamous cell carcinoma revealed by proteomic analysis. BMC Genomics. 2009;10:383.

76. Xie X, Jiang Y, Yuan Y, Wang P, Li X, Chen F, et al. MALDI imaging reveals NCOA7 as a potential biomarker in oral squamous cell carcinoma arising from oral submucous fibrosis. Oncotarget. 2016;7(37):59987-60004.

77. Yang CM, Chang HS, Chen HC, You J, Liou HH, Ting SC, et al. Low C6orf141 expression is significantly associated with a poor prognosis in patients with oral cancer. Sci Rep. 2019;9(1):4520.

78. Yu B, Cao W, Zhang C, Xia R, Liu J, Yan M, et al. Prediction of lymph node metastasis in oral squamous cell carcinoma based on protein profile. Expert Rev Proteomics. 2019;16(4):363-73.

79. Yuan $Y$, Xie $X$, Jiang $Y$, Wei Z, Wang P, Chen F, et al. LRP6 is identified as a potential prognostic marker for oral squamous cell carcinoma via MALDI-IMS. Cell Death Dis. 2017;8(9):e3035.

80. Ziebart T, Walenta S, Kunkel M, Reichert TE, Wagner W, Mueller-Klieser W. Metabolic and proteomic differentials in head and neck squamous cell carcinomas and normal gingival tissue. J Cancer Res Clin Oncol. 2011;137(2):193-9.

81. Schaaij-Visser BM. Biomarker discovery for head and neck cancer. A proteomics approach. The Netherlands: Ipskamp Drukkers B.V., Enschede; 2010.

82. Tung $\mathrm{CL}$, Lin ST, Chou HC, Chen YW, Lin HC, Tung CL, et al. Proteomicsbased identification of plasma biomarkers in oral squamous cell carcinoma. J Pharm Biomed Anal. 2013;75:7-17.

83. Bijian K, Mlynarek AM, Balys RL, Jie S, Xu Y, Hier MP, et al. Serum proteomic approach for the identification of serum biomarkers contributed by oral squamous cell carcinoma and host tissue microenvironment. J Proteome Res. 2009;8(5):2173-85.

84. Chu HW, Chang KP, Hsu CW, Chang IY, Liu HP, Chen YT, et al. Identification of salivary biomarkers for oral cancer detection with untargeted and targeted quantitative proteomics approaches. Mol Cell Proteomics. 2019;18(9):1796-806.

85. Kang S, Chen J. Targeting RSK2 in human malignancies. Expert Opin Ther Targets. 2011;15(1):11-20.

86. Elf S, Blevins D, Jin L, Chung TW, Williams IR, Lee BH, et al. p90RSK2 is essential for FLT3-ITD- but dispensable for BCR-ABL-induced myeloid leukemia. Blood. 2011;117(25):6885-94.

87. Clark DE, Errington TM, Smith JA, Frierson HF Jr, Weber MJ, Lannigan DA. The serine/threonine protein kinase, p90 ribosomal 56 kinase, is an important regulator of prostate cancer cell proliferation. Cancer Res. 2005:65(8):3108-16.

88. Hu S, Arellano M, Boontheung P, Wang J, Zhou H, Jiang J, et al. Salivary proteomics for oral cancer biomarker discovery. Clin Cancer Res. 2008;14(19):6246-52

89. Wu CC, Chien KY, Tsang NM, Chang KP, Hao SP, Tsao CH, et al. Cancer cell-secreted proteomes as a basis for searching potential tumour markers: nasopharyngeal carcinoma as a model. Proteomics. 2005;5(12):3173-82

90. Sapkota D, Bruland O, Bøe OE, Bakeer H, Elgindi OA, Vasstrand EN, et al. Expression profile of the $\mathrm{S} 100$ gene family members in oral squamous cell carcinomas. J Oral Pathol Med. 2008;37(10):607-15.

91. Ravindranath NM, Shuler C. Cell-surface density of complement restriction factors (CD46, CD55, and CD59): oral squamous cell carcinoma versus other solid tumours. Oral Surg Oral Med Oral Pathol Oral Radiol Endod. 2007;103(2):231-9.

92. Xie H, Onsongo G, Popko J, de Jong EP, Cao J, Carlis JV, et al. Proteomics analysis of cells in whole saliva from oral cancer patients via 
value-added three-dimensional peptide fractionation and tandem mass spectrometry. Mol Cell Proteomics. 2008;7(3):486-98.

93. Jessie K, Jayapalan JJ, Ong KC, Abdul Rahim ZH, Zain RM, Wong KT, et al. Aberrant proteins in the saliva of patients with oral squamous cell carcinoma. Electrophoresis. 2013;34(17):2495-502.

94. Jou YJ, Lin CD, Lai CH, Tang CH, Huang SH, Tsai MH, et al. Salivary zinc finger protein 510 peptide as a novel biomarker for detection of oral squamous cell carcinoma in early stages. Clin Chim Acta. 2011:412(15-16):1357-65.

95. Jou YJ, Lin CD, Lai CH, Chen CH, Kao JY, Chen SY, et al. Proteomic identification of salivary transferrin as a biomarker for early detection of oral cancer. Anal Chim Acta. 2010;681(1-2):41-8.

96. Shpitzer T, Hamzany Y, Bahar G, Feinmesser R, Savulescu D, Borovoi I, et al. Salivary analysis of oral cancer biomarkers. Br J Cancer. 2009;101(7):1194-8

97. He H, Chen G, Zhou L, Liu Y. A joint detection of CEA and CA-50 levels in saliva and serum of patients with tumours in oral region and salivary gland. J Cancer Res Clin Oncol. 2009:135(10):1315-21.

98. Hsiao YC, Chi LM, Chien KY, Chiang WF, Chen SF, Chuang YN, et al. Development of a multiplexed assay for oral cancer candidate biomarkers using peptide immunoaffinity enrichment and targeted mass spectrometry. Mol Cell Proteomics. 2017;16(10):1829-49.

99. Shpitzer T, Bahar G, Feinmesser R, Nagler RM. A comprehensive salivary analysis for oral cancer diagnosis. J Cancer Res Clin Oncol. 2007:133(9):613-7.

100. He Y, Shao F, Pi W, Shi C, Chen Y, Gong D, et al. Largescale transcriptomics analysis suggests over-expression of BGH3, MMP9 and PDIA3 in oral squamous cell carcinoma. PLoS One. 2016;1 1(1):e0146530.

101. Franzmann EJ, Reategui EP, Pedroso F, Pernas FG, Karakullukcu BM, Carraway $\mathrm{KL}$, et al. Soluble CD44 is a potential marker for the early detection of head and neck cancer. Cancer Epidemiol Biomarkers Prev. 2007;16(7):1348-55.

102. Arellano-Garcia ME, Li R, Liu X, Xie Y, Yan X, Loo JA, et al. Identification of tetranectin as a potential biomarker for metastatic oral cancer. Int J Mol Sci. 2010;11(9):3106-21.

103. Brinkmann O, Kastratovic DA, Dimitrijevic MV, Konstantinovic VS, Jelovac $D B$, Antic J, et al. Oral squamous cell carcinoma detection by salivary biomarkers in a Serbian population. Oral Oncol. 2011:47(1):51-5.

104. Csősz É, Lábiscsák P, Kalló G, Márkus B, Emri M, Szabó A, et al. Proteomics investigation of OSCC-specific salivary biomarkers in a Hungarian population highlights the importance of identification of populationtailored biomarkers. PLoS One. 2017:12(5):e0177282.

105. Gleber-Netto FO, Yakob M, Li F, Feng Z, Dai J, Kao HK, et al. Salivary biomarkers for detection of oral squamous cell carcinoma in a Taiwanese population. Clin Cancer Res. 2016;22(13):3340-7.

106. Elashoff D, Zhou H, Reiss J, Wang J, Xiao H, Henson B, et al. Prevalidation of salivary biomarkers for oral cancer detection. Cancer Epidemiol Biomarkers Prev. 2012;21(4):664-72.

107. Nassar AF, Williams BJ, Yaworksy DC, Patel V, Rusling JF. Rapid label-free profiling of oral cancer biomarker proteins using nano-UPLC-Q-TOF ion mobility mass spectrometry. Proteomics Clin Appl. 2016;10(3):280-9.

108. Camisasca DR, da Rós Gonçalves L, Soares MR, Sandim V, Nogueira FC, Garcia $\mathrm{CH}$, et al. A proteomic approach to compare saliva from individuals with and without oral leukoplakia. J Proteomics. 2017;151:43-52.

109. Wong YL, Ramanathan A, Yuen KM, Mustafa WMW, Abraham MT, Tay KK, et al. Comparative sera proteomics analysis of differentially expressed proteins in oral squamous cell carcinoma. Peer. 2021;9:e11548.

110. Chen YT, Chen HW, Wu CF, Chu LJ, Chiang WF, Wu CC, et al. Development of a multiplexed liquid chromatography multiple-reactionmonitoring mass spectrometry (LC-MRM/MS) method for evaluation of salivary proteins as oral cancer biomarkers. Mol Cell Proteomics. 2017:16(5):799-811.

111. Chi LM, Hsiao YC, Chien KY, Chen SF, Chuang YN, Lin SY, et al. Assessment of candidate biomarkers in paired saliva and plasma samples from oral cancer patients by targeted mass spectrometry. J Proteomics. 2020:211:103571.

112. Hsiao YC, Lin SY, Chien KY, Chen SF, Wu CC, Chang YT, et al. An immunoMALDI mass spectrometry assay for the oral cancer biomarker, matrix metalloproteinase-1, in dried saliva spot samples. Anal Chim Acta. 2020;1100:118-30.
113. de Jong EP, Xie H, Onsongo G, Stone MD, Chen XB, Kooren JA, et al. Quantitative proteomics reveals myosin and actin as promising saliva biomarkers for distinguishing pre-malignant and malignant oral lesions. PLoS One. 2010;5(6):e11148

114. Guo H, Jiang W, Huang S, Huang X, Li C. Serum exosome-derived biomarkers for the early detection of oral squamous cell carcinoma. Mol Cell Biochem. 2021. https://doi.org/10.1007/s11010-021-04254-7.

115. Heawchaiyaphum C, Pientong C, Phusingha P, Vatanasapt P, Promthet $\mathrm{S}$, Daduang J, et al. Peroxiredoxin-2 and zinc-alpha-2-glycoprotein as potentially combined novel salivary biomarkers for early detection of oral squamous cell carcinoma using proteomic approaches. J Proteomics. 2018:173:52-61.

116. Jancsik VA, Gelencser G, Maasz G, Schmidt J, Molnar GA, Wittmann I, et al. Salivary proteomic analysis of diabetic patients for possible oral squamous cell carcinoma biomarkers. Pathol Oncol Res. 2014;20(3):591-5.

117. Ishikawa S, Ishizawa K, Tanaka A, Kimura H, Kitabatake K, Sugano A, et al. Identification of salivary proteomic biomarkers for oral cancer screening. In Vivo. 2021;35(1):541-7.

118. Scholtz B, Vo Minh D, Kiss C, Tar I, Kumar A, Tőzsér J, et al. Examination of oral squamous cell carcinoma and precancerous lesions using proximity extension assay and salivary RNA quantification. Biomedicines. 2020;8(12):610. https://doi.org/10.3390/biomedicines8120610.

119. Usman M, llyas A, Hashim Z, Zarina S. Identification of GIMAP7 and Rabl3 as putative biomarkers for oral squamous cell carcinoma through comparative proteomic approach. Pathol Oncol Res. 2020;26(3):1817-22

120. Usman M, llyas A, Syed B, Hashim Z, Ahmed A, Zarina S. Serum HSP90alpha and oral squamous cell carcinoma: a prospective biomarker. Protein Pept Lett. 2021. https://doi.org/10.2174/092986652866621 0616112539.

121. Wu CC, Chu HW, Hsu CW, Chang KP, Liu HP. Saliva proteome profiling reveals potential salivary biomarkers for detection of oral cavity squamous cell carcinoma. Proteomics. 2015;15(19):3394-404.

122. Yang Y, Rhodus NL, Ondrey FG, Wuertz BR, Chen X, Zhu Y, et al. Quantitative proteomic analysis of oral brush biopsies identifies secretory leukocyte protease inhibitor as a promising, mechanism-based oral cancer biomarker. PLoS One. 2014;9(4):e95389.

123. Yu CJ, Chang KP, Chang YJ, Hsu CW, Liang Y, Yu JS, et al. Identification of guanylate-binding protein 1 as a potential oral cancer marker involved in cell invasion using omics-based analysis. J Proteome Res. 2011:10(8):3778-88

124. Lo WY, Wang HJ, Chiu CW. Chen SF: miR-27b-regulated TCTP as a novel plasma biomarker for oral cancer: from quantitative proteomics to posttranscriptional study. J Proteomics. 2012;77:154-66.

125. Warnakulasuriya S, Soussi T, Maher R, Johnson N, Tavassoli M. Expression of p53 in oral squamous cell carcinoma is associated with the presence of $\lg \mathrm{G}$ and $\lg$ A p53 autoantibodies in sera and saliva of the patients. J Pathol. 2000;192(1):52-7.

126. Fujita Y, Nakanishi T, Miyamoto Y, Hiramatsu M, Mabuchi H, Miyamoto A, et al. Proteomics-based identification of autoantibody against heat shock protein 70 as a diagnostic marker in esophageal squamous cell carcinoma Cancer Lett. 2008:263(2):280-90.

127. Murase R, Abe Y, Takeuchi T, Nabeta M, Imai Y, Kamei Y, et al. Serum autoantibody to sideroflexin 3 as a novel tumour marker for oral squamous cell carcinoma. Proteomics Clin Appl. 2008;2(4):517-27.

128. Blot WJ, McLaughlin JK, Winn DM, Austin DF, Greenberg RS, PrestonMartin S, et al. Smoking and drinking in relation to oral and pharyngeal cancer. Cancer Res. 1988:48(11):3282-7.

129. Scully C, Field JK, Tanzawa H. Genetic aberrations in oral or head and neck squamous cell carcinoma (SCCHN): 1. Carcinogen metabolism, DNA repair and cell cycle control. Oral Oncol. 2000;36(3):256-63.

130. Lieber CS. Cytochrome P-4502E1: its physiological and pathological role. Physiol Rev. 1997;77(2):517-44.

131. Kriek E, Rojas M, Alexandrov K, Bartsch H. Polycyclic aromatic hydrocarbon-DNA adducts in humans: relevance as biomarkers for exposure and cancer risk. Mutat Res. 1998;400(1-2):215-31.

132. Schaaij-Visser TB, Brakenhoff RH, Leemans CR, Heck AJ, Slijper M. Protein biomarker discovery for head and neck cancer. J Proteomics. 2010;73(10):1790-803. 
133. Jaiswal R, Pandey M. Human papilloma virus in oral carcinogenesis and its routes of transmission. World J Epidemiol Cancer Prevention. 2012;1(1):1-9.

134. Hahn M, Hagedorn G, Kuhlisch E, Schackert HK, Eckelt U. Genetic polymorphisms of drug-metabolizing enzymes and susceptibility to oral cavity cancer. Oral Oncol. 2002;38(5):486-90.

135. Sreelekha TT, Ramadas K, Pandey M, Thomas G, Nalinakumari KR, Pillai MR. Genetic polymorphism of CYP1A1, GSTM1 and GSTT1 genes in Indian oral cancer. Oral Oncol. 2001;37(7):593-8.

136. Kutler DI, Auerbach AD, Satagopan J, Giampietro PF, Batish SD, Huvos $A G$, et al. High incidence of head and neck squamous cell carcinoma in patients with Fanconi anemia. Arch Otolaryngol Head Neck Surg. 2003;129(1):106-12

137. de Winter JP, Joenje $\mathrm{H}$. The genetic and molecular basis of Fanconi anemia. Mutat Res. 2009;668(1-2):11-9.

138. Neville BW, Day TA. Oral cancer and precancerous lesions. CA Cancer J Clin. 2002;52(4):195-215.

139. Arroyo EA, Donís SP, Petronacci CMC, Alves MGO, Mendía XM, Fernandes $D$, et al. Usefulness of protein-based salivary markers in the diagnosis of oral potentially malignant disorders: a systematic review and meta-analysis. Cancer Biomark. 2021. https://doi.org/10.3233/ CBM-203043.

140. Kasradze D, Juodzbalys G, Guobis Z, Gervickas A, Cicciù M. Genetic and proteomic biomarkers of head-and-neck cancer: a systematic review. J Cancer Res Ther. 2020;16(3):410-24.

141. Saraswat M, Mäkitie A, Agarwal R, Joenväärä S, Renkonen S. Oral squamous cell carcinoma patients can be differentiated from healthy individuals with label-free serum proteomics. Br J Cancer. 2017;117(3):376-84

142. Saraswat M, Mäkitie A, Tohmola T, Dickinson A, Saraswat S, Joenväärä $S$, et al. Tongue cancer patients can be distinguished from healthy controls by specific N-glycopeptides found in serum. Proteomics Clin Appl. 2018;12(6):e1800061.

143. Sivadasan P, Gupta MK, Sathe GJ, Balakrishnan L, Palit P, Gowda H, et al. Human salivary proteome--a resource of potential biomarkers for oral cancer. J Proteomics. 2015;127(Pt A):89-95.

144. Winck FV, Prado Ribeiro AC, Ramos Domingues R, Ling LY, Riaño-Pachón DM, Rivera $C$, et al. Insights into immune responses in oral cancer through proteomic analysis of saliva and salivary extracellular vesicles. Sci Rep. 2015:5:16305.
145. Li C, Zhou Y, Liu J, Su X, Qin H, Huang S, et al. Potential markers from serum-purified exosomes for detecting oral squamous cell carcinoma metastasis. Cancer Epidemiol Biomarkers Prev. 2019;28(10):1668-81.

146. Malik UU, Siddiqui IA, Ilyas A, Hashim Z, Staunton L, Kwasnik A, et al. Identification of differentially expressed proteins from smokeless tobacco addicted patients suffering from oral squamous cell carcinoma. Pathol Oncol Res. 2020;26(3):1489-97.

147. Mohanty V, Subbannayya Y, Patil S, Abdulla R, Ganesh MS, Pal A, et al. Molecular alterations in oral cancer between tobacco chewers and smokers using serum proteomics. Cancer Biomark. 2021;31(4):361-73.

148. Penteado CAS, Batista TBD, Chaiben CL, Bonacin BG, Ventura TMO, Dionizio A, et al. Salivary protein candidates for biomarkers of oral disorders in alcohol and tobacco dependents. Oral Dis. 2020. https://doi.org/ 10.1111/odi.13337.

149. Brennan JA, Boyle JO, Koch WM, Goodman SN, Hruban RH, Eby YJ, et al. Association between cigarette smoking and mutation of the p53 gene in squamous-cell carcinoma of the head and neck. N Engl J Med. 1995:332(11):712-7.

150. Koehn J, Krapfenbauer K, Huber S, Stein E, Sutter W, Watzinger F, et al. Potential involvement of MYC- and p53-related pathways in tumourigenesis in human oral squamous cell carcinoma revealed by proteomic analysis. J Proteome Res. 2008;7(9):3818-29.

151. Batta N, Pandey M. Mutational spectrum of tobacco associated oral squamous carcinoma and its therapeutic significance. World J Surg Oncol. 2019;17(1):198

152. Marcu LG, Yeoh E. A review of risk factors and genetic alterations in head and neck carcinogenesis and implications for current and future approaches to treatment. J Cancer Res Clin Oncol. 2009:135(10):1303-14.

153. Hardisson D. Molecular pathogenesis of head and neck squamous cell carcinoma. Eur Arch Otorhinolaryngol. 2003;260(9):502-8.

154. Ai L, Stephenson KK, Ling W, Zuo C, Mukunyadzi P, Suen JY, et al. The p16 (CDKN2a/INK4a) tumour-suppressor gene in head and neck squamous cell carcinoma: a promoter methylation and protein expression study in 100 cases. Mod Pathol. 2003;16(9):944-50.

\section{Publisher's Note}

Springer Nature remains neutral with regard to jurisdictional claims in published maps and institutional affiliations.
Ready to submit your research? Choose BMC and benefit from:

- fast, convenient online submission

- thorough peer review by experienced researchers in your field

- rapid publication on acceptance

- support for research data, including large and complex data types

- gold Open Access which fosters wider collaboration and increased citations

- maximum visibility for your research: over 100M website views per year

At BMC, research is always in progress.

Learn more biomedcentral.com/submissions 